\title{
A Topographical Map of the Causal Network of Mechanisms Underlying the Relationship Between Major Depressive Disorder and Coronary Heart Disease.
}

N.J.C. Stapelberg, D.L. Neumann, D.H.K. Shum, H. McConnell, I. Hamilton-Craig

Running Title: Depression and Heart Disease: A Causal Network

\section{Degrees and Affiliations}

Dr Nicolas J.C. Stapelberg

BSc (Hons), MBBS, FRANZCP

School of Psychology and Griffith Health Institute, Griffith University

Parklands Drive

Southport Queensland 4215, Australia

Ph: 001161755260248

E-mail: shaia@shaia.net

No conflicts of interest

Dr David L. Neumann

BSc (Hons), $\mathrm{PhD}$

School of Psychology and Griffith Health Institute, Griffith University

No conflicts of interest

Professor David H. K. Shum

BA Hons, $\mathrm{PhD}$

School of Psychology and Griffith Health Institute, Griffith University 
Professor Harry McConnell

MD FRCPC FRANZCP

Clinical Sub Dean

Professor of Neuropsychiatry

School of Medicine, Griffith University

No conflicts of interest

Professor Ian Hamilton-Craig

MBBS (Adel), PhD (McMaster), FRACP, FCSANZ, FLS (Lond)

Professor of Internal Medicine and Preventive Cardiology

School of Medicine, Griffith University

No conflicts of interest

This research has been supported by a grant from the Gold Coast Hospital

Foundation, Queensland, Australia. The funding organization had no role in the collection, management, analysis, or interpretation of the review information; or preparation, review, or approval of the manuscript.

Word Count: Abstract 252, Text: 6549. 


\title{
A Topographical Map of the Causal Network of Mechanisms Underlying the Relationship Between Major Depressive Disorder and Coronary Heart Disease.
}

N.J.C. Stapelberg, D.L. Neumann, D.H.K. Shum, H. McConnell, I. Hamilton-Craig

\begin{abstract}
Objective

Major Depressive Disorder (MDD) and Coronary Heart Disease (CHD) are both clinically important public health problems. Depression is linked with a higher incidence of ischaemic cardiac events and MDD is more prevalent in patients with CHD. No single comprehensive model has yet described the causal mechanisms linking MDD to CHD. Several key mechanisms have been put forward, comprising behavioural mechanisms, genetic mechanisms, dysregulation of immune mechanisms, coagulation abnormalities and vascular endothelial dysfunction, polyunsaturated omega-3 free fatty acid deficiency, and autonomic mechanisms. It has been suggested that these mechanisms form a network, which links MDD and CHD.

The aim of this review is to examine the causal mechanisms underlying the relationship between MDD and $\mathrm{CHD}$, with the aim of constructing a topological map of the Causal Network which describes the relationship between MDD and CHD.

\section{Methods}

The search term "depression and heart disease" was entered into an electronic multiple database search engine. Abstracts were screened for relevance and individually selected articles were collated.

\section{Results}

This review introduces the first topological map of the Causal Network which describes the relationship between MDD and CHD. 


\section{Conclusions}

Viewing the causal pathways as an interdependent network presents a new paradigm in this field and provides fertile ground for further research. The Causal Network can be studied using the methodology of Systems Biology, which is briefly introduced. Future research should focus on the creation of a more comprehensive topological map of the Causal Network the quantification of the activity between each node of the Causal Network.

\section{Key Words}

Major Depressive Disorder, Coronary Heart Disease, Causal Mechanisms, Causal Network, Systems Biology, Topological Map

\section{Acronyms}

$\mathrm{ACTH}=$ Adrenocorticotropic Hormone

$\mathrm{AMI}=$ Acute Myocardial Infarction

$\mathrm{CAD}=$ Coronary Artery Disease

$\mathrm{CHD}=$ Coronary Heart Disease

$\mathrm{CNS}=$ Central Nervous System

$\mathrm{CRH}=$ Corticotropin-Releasing Hormone

$\mathrm{CVC}=$ Cardiac Vagal Control

CVD $=$ Cardiovascular Disease

DALYs $=$ Disability Adjusted Life Years

DHA $=$ Docosahexaenoic Acid

$\mathrm{EPA}=$ Eicosapentaenoic Acid 
HPA $=$ Hypothalamic-Pituitary-Adrenal

HRV $=$ Heart Rate Variability

ICAM $=$ Intercellular adhesion molecules

IHD $=$ Ischaemic Heart Disease

$\mathrm{IL}=$ Interleukin

MDD $=$ Major Depressive Disorder

$\mathrm{MI}=$ Myocardial Infarction

PUFA $=$ Polyunsaturated Fatty Acid

SSRI $=$ Selective Serotonin Reuptake Inhibitor 


\section{Context: The Global Significance of Depression and Coronary Heart Disease}

Depression and coronary heart disease are important global public health problems. Depression is one of the largest causes of morbidity worldwide and contributing heavily to estimates of global burden of disease[1]. Major Depressive Disorder (MDD) is also a significant problem in people with co-morbid medical illness. An average of between $9.3 \%$ and $23.0 \%$ of individuals with one or more chronic physical disease has co-morbid depression[2]. Similarly, Coronary Heart Disease (CHD) causes a significant burden of disease and is a leading cause of mortality and morbidity worldwide. The worldwide prevalence of angina pectoris (a readily identifiable illness related to CHD) is 54 million people worldwide[3].

It is well established that there is a link between MDD and CHD[4-9]. Additionally, depression and CHD have a complex reciprocal interrelationship, where depressive illness leads to ischaemic heart disease, and heart disease leads to depression[10, 11]. Depression has been linked with a 3- to 4-fold increase in the risk of recurrent cardiac events as well as death[12]. Depression also increases the risk of future cardiac mortality and morbidity in patients with coronary artery disease[13, 14]. Conversely, people with CHD have an approximately three times higher prevalence of depression than healthy people[15]. Thombs et al.[16] found that major depression is also three times more common in patients after an acute myocardial infarction (AMI) than in the general population.

\section{Objective}

If links between CHD and MDD exist, it raises the possibility that common mechanisms could be identified which link these diseases. Moreover, this knowledge could then be applied to improve prevention and treatment for both conditions. However, despite strong evidence for a link between depression and CHD, there is no 
single comprehensive model that describes the mechanism for this relationship[17]. Several individual pathways have been described. These pathways have typically been discussed as separate entities in empirical research and reviews have described a small number of related mechanisms in detail. For example, both Tracey[18] and Musselman et al.[7] provide excellent reviews of the relationship between autonomic mechanisms and inflammatory mechanisms linking MDD and CHD. However, there is considerable overlap and inter-connectivity between all known mechanisms, to the point where these previously discretely described causal mechanisms should be seen as a network of pathogenic determinants.

De Jonge et al. (in press) reviewed the possible mechanisms by which MDD and CHD may be related[19]. The authors identified the relationship between MDD and CHD as a complex system, or network, and suggest that the network might be studied using systems biology. This idea was not further explored however. While the paper offers a lucid review of the literature around the causal pathways linking MDD and CHD, it did not provide a topological map of this network or suggest how systems biology might be applied to it. It also does not adequately address the behavioural mechanisms linking MDD and CHD, which forms and integral component of the overall relationship of MDD and CHD.

The aim of this review is to present the key mechanisms linking major depression and CHD that have been described in the literature, with the aim of constructing a topological map of the Causal Network which describes the relationship between MDD and CHD. This review will also explore the concept that Systems Biology, which deals with the study of biological networks, can provide a useful framework to investigate the relationship between the two disease entities. 
The relationship between MDD and CHD has also been discussed in the context of other mental disorders, such as anxiety disorders, or personality and character traits (e.g. Rozanski et al.[15]). While the study of such relationships may yield further proposed mechanisms which contribute to the Causal Network between MDD and CHD, they fall beyond the scope of this review.

\section{Study Selection}

The search term "depression and heart disease" was entered into an electronic multiple database search engine, "Griffith University Library Multiple Database Search", which searched the following databases: MEDLINE 1950 to present (Ovid), BioMed Central, BMJ Clinical Evidence, BMJ Journals Online, Cambridge Journals Online, Highwire Press, IngentaConnect, LANGE Educational Library, Lippincott, Williams \& Wilkins e-journals (Ovid), LOCATORplus, Medi-Lexicon, MEDLINE (EBSCOhost), MEDLINE (via PubMed), MEDLINE - OLDMEDLINE 1951-1965 (Ovid), MEDLINE In-Process (Ovid), Oxford Journals Online, PLoS: Public Library of Science, ProQuest (multiple databases), ProQuest Dissertations and Theses - Full Text, PsycINFO (Ovid), PubMed, ScienceDirect, ScienceDirect: Medicine and Dentistry, SCIRUS (Elsevier), SpringerLink, STAT!Ref: Nursing and Allied Health Collection, SUMSearch, SwetsWise, Taylor and Francis ebook collection, Web of Knowledge (ISI), Web of Science (ISI) and Wiley InterScience. No constraints were applied to the search. Abstracts were screened for relevance and individually selected articles were then collated. The reference lists of relevant articles were then screened for further articles of interest. Articles were selected on the basis of (1) specifically addressing causal mechanisms, (2) including discussions of aetiology including common behaviours, genetics and/or physiological abnormalities or medical co 
morbidity between the diagnoses, and (3) those articles specifically addressing the outcomes, prognosis and/or treatment related issues linking depression and cardiac disease.

\section{Mechanisms which link Coronary Heart Disease and Depression}

Six principal mechanisms have been put forward to explain the link between major depression and CHD: (a) behavioural mechanisms, (b) genetic mechanisms, (c) dysregulation of immune mechanisms, (d) coagulation abnormalities and vascular endothelial dysfunction, (e) polyunsaturated omega-3 free fatty acid deficiency, and (f) autonomic mechanisms. Other mechanisms have been implicated in the relationship between MDD and CHD, but have little supporting evidence to date. For example, antidepressant cardiotoxicity is suggested to account for the increased incidence of adverse cardiac events in depressed people[20]. However, this is unlikely to represent a significant mechanism. The observed relationship between MDD and CHD precedes the development of antidepressant medications, selective serotonin reuptake inhibitors (SSRIs), which are now the first line of pharmacological therapy for depression, have few cardiotoxic side effects, and the cardiotoxic reactions to antidepressants are generally not severe or life threatening[20].

Although the newer generation of antidepressants has many advantages from a cardiac perspective over tricylcics, the role of antidepressant cardiotoxity as a confounding variable cannot be excluded here as SSRIs may also have significant cardiac effects. These have been reviewed by Pacher and Kecskemeti who point out the significant effects of SSRIs clinically in reports where they have been shown to produce bradycardia, QT prolongation, decreased T wave amplitude, dysrthymia, syncope and falls, and effects on the vasomotor centre and blood pressure[21]. They 
have also been shown to affect cellular physiology in vitro with effects on cardiac action potentials and on cardiac ion channels.

\section{Behavioural Mechanisms}

Depressed people tend to engage in poor health behaviours such as smoking, low physical activity and maintaining a poor $\operatorname{diet}[15,17]$. As a result they have increased rates of obesity and diabetes, which are risk factors for cardiac disease[22].

Depression has been identified as a risk factor for diabetes[23-25] and diabetes in turn is a risk factor for coronary heart disease[26]. Depression is also linked to increased rates of obesity[27, 28]. In a large prospective cohort study, where 2088 people were followed up over 5 years, depressed participants showed a significantly greater increase in abdominal obesity, especially in visceral fat, than non-depressed people[29]. A meta-analysis of 15 studies on the relationship between obesity and MDD confirmed a reciprocal link between depression and obesity[30]. Obesity was thus found to increase the risk of depression, but additionally, depression was found to be a predictor for developing obesity. Links between obesity and sympathetic autonomic dysfunction in depression are discussed in Autonomic Mechanisms below.

The metabolic syndrome is a combination of metabolic conditions which increase the risk of developing cardiovascular disease and insulin resistance. Conditions associated with the metabolic syndrome, namely obesity, diabetes, and hyperglycemia, have also been associated with the presence of depression[31]. In both men and women, the metabolic syndrome has been associated with an increased prevalence of depression[32]. This association between the metabolic syndrome and depressive illness was independent of age, smoking status, socioeconomic factors, and lifestyle. The metabolic syndrome, in turn, has been associated with significantly increased risk of all cause and cardiovascular morbidity and mortality[33-35]. 
In addition, depressed people have maladaptive coping styles, suffer from chronic life stresses and have increased rates of social isolation and poorer social skills[36-38]. Depressed patients are also less likely to adhere to medical treatment, contributing to poor health outcomes[20, 39, 40].

Social isolation in particular has been shown to contribute significantly to poor cardiac health and even increased cardiac mortality[41]. While objectively poor social support networks are associated with a two- to three-fold increase in the incidence of CHD over time, low levels of perceived emotional support by the patient also result in an increased risk of future adverse cardiac events[15]. An almost three-fold increase in subsequent adverse cardiac events has been found in patients post-MI who had low levels of emotional support[42]. The direction of causality between social support and depression is still not clear however, even though these variables have been shown to influence each other[43]. Inadequate social support and social isolation may lead to depression, particularly in the context of a significant stressor such as an MI[44].

Psychological distress, low self-esteem and impairment in occupational and social functioning occurs in patients after MI[45, 46]. While psychological distress in such studies is discussed along with depressive illness and anxiety symptoms, the question whether stress and distress following an MI then lead to further deterioration in the form of MDD is not entirely clear. It could be argued, however, that factors such as distress around loss of function post-MI, for example, combined with factors such as limited social support, could directly contribute to an increased risk of MDD. Depressed patients have higher rates of daily smoking and nicotine dependence[47, 48] and are less likely to give up smoking[49-52]. Cigarette smokers have almost three times the rate of acute MI as compared with non-smokers[53], 
potentially establishing a causal link between increased smoking behaviour in MDD and the increased incidence of CVD.

The behavioural mechanisms are summarised in Figure 1. Despite the above evidence, however, there is an increase in cardiac disease risk in depressed patients even after cardiac risk factors such as smoking are statistically adjusted for. Thus, while behavioural factors play a role in increasing the risk of cardiac disease in depressed patients, they do not on their own account for the link between the two disease entities.

\section{[Insert Figure 1 about here]}

\section{Genetic Mechanisms}

There is some evidence to support a theory of genetic mechanisms which link MDD and CHD. Attempts have been made to extend such theory to MDD in the context of cardiovascular disease. Despite some promising findings[54], the genetic mechanisms linking depression and cardiovascular disease are complex and this field still requires much further research. While a comprehensive examination is beyond the scope of this review, some of the pertinent findings are discussed below.

The 5-HTT serotonin transporter gene codes for the serotonin transporter protein, which facilitates the reuptake of serotonin from the synaptic cleft in serotonergic neurons. Genetic polymorphism of the serotonin transporter gene has been implicated in the pathogenesis of MDD[55-57]. People who have one or two short alleles of the 5-HTT serotonin transporter gene, become depressed more often after stressful events than people who have two long alleles of this gene[58]. The short allele of this polymorphism can reduce the transcription efficiency of the gene, resulting in reduced expression of the serotonin transporter in the membrane of the 
pre-synaptic neuron. The short allele has been shown to predict depression in the presence of stressful life events[58-65], although the mechanism by which it results in MDD is still not known[66]. There is also evidence of the short allele being associated with MDD in patients after suffering an acute coronary syndrome[67]. A possible link also exists between the short allele of the serotonin transporter genome and sympathetic nervous activation. Otte et al.[66] demonstrated that among people who were carriers of the short allele and who had stable CHD, there was an increased risk of depression, an increase in perceived stress levels, as well as increased secretion of noradrenaline. Increased sympathetic activation in turn has been linked to CHD, as discussed in the section on Autonomic Mechanisms below.

The serotonin transporter protein (5-HTT) is also the site of action of antidepressants which block serotonin reuptake from the synapse[68, 69]. Common genetic polymorphisms of several monoamine systems, such as 5-HTT, MAO-A or COMT, have been studied as candidate genes for mood disorders[70]. However, it has also been proposed that the serotonin transporter gene functional polymorphism may confer susceptibility for some cardiovascular risk factors as well as for mood disorders[70]. The hypothesis has thus been proposed that serotonin transporter gene functional polymorphism could also represent a mechanism for depression-related increased cardiovascular morbidity and mortality[70]. There is however little direct evidence of the genetic contribution to depressive symptoms with CVD[54]. A candidate gene study on French-Canadian subjects with established CVD focused on genes related to inflammation, platelet aggregation, endothelial function and omega-3 fatty acid metabolism as predictors of depressive symptoms[54]. The study found that genetic variation in genes relevant to endothelial dysfunction and platelet aggregation could contribute to depression in cardiac patients. This study thus relates possible 
genetic mechanisms to inflammatory mechanisms, endothelial dysfunction and platelet activation.

The relationships between these mechanisms are shown in Figure 2.

$$
\text { [Insert Figure } 2 \text { about here] }
$$

\section{Inflammatory Mechanisms}

Dysregulation of immune mechanisms involving proinflammatory cytokines in major depression can cause $\mathrm{CHD}$ [71-73]. People with a depressive illness have a dysregulation of immune mechanisms involving pro-inflammatory cytokines, which include elevated levels of interleukins (IL) such as IL-1, IL-2, IL-6, tumor necrosis factor and acute phase proteins such as C-reactive protein[71-77]. Increased levels of these inflammatory markers have been linked to cardiac diseases such as congestive heart failure, coronary heart disease, and MI[78-80].

Atherosclerotic lesions have been postulated to stimulate a chronic, low-grade immune activation, resulting in increased production of cytokines[81]. Conversely, inflammation may be linked to an increased rate of atherosclerosis, which in turn confers greater risk of adverse cardiac events[82]. Atherosclerosis is not only a risk factor for CHD, but it has also been suggested that atherosclerosis independently causes both depressive and cardiac illness, possibly simultaneously[83]. Increased levels of cytokines can result in depressive symptoms such as loss of appetite, fatigue, and also apathy and social withdrawal[83]. Attempts to show that there is a cumulative effect with regards to cytokine levels in patients with depression as well as heart disease have been inconclusive, however[12, 84]. If both depression and illnesses such as CHD are caused by a third entity such as atherosclerosis, this may explain such a finding. 
In addition, it has been suggested that autonomic neural pathways reflexively monitor and adjust the inflammatory response. A review by Tracey[18] has postulated the existence of a neuro-inflammatory reflex, where inflammatory stimuli activate sensory pathways that relay information to the hypothalamus, which in turn activates an anti-inflammatory response. There is evidence showing that the neural control of acute inflammation is reflexive and can inhibit the activation of macrophages and the release of cytokines via the vagus nerve. Thus, if stimulation of the vagus nerve can inhibit the release of cytokines and counteract an inflammatory response[18], it could thus be postulated that vagal dysfunction could result in increased inflammatory markers, contributing to CHD.

The relationships discussed above are depicted in Figure 3. Empana et al.[80] also found that depressed mood is related to CHD even after adjustment for inflammatory markers, suggesting that they are not the sole mechanisms accounting for the association between depression and CHD.

$$
\text { [Insert Figure } 3 \text { about here] }
$$

\section{Endothelial Dysfunction and Platelet Activation}

Coagulation abnormalities and vascular endothelial dysfunction are thought to cause the development of, or acceleration of, atherosclerosis in people with depression, via raised platelet activation or increased levels of immune cells[85-87]. There is good evidence for a link between mental stress and endothelial function. Acute psychological stress was shown to cause transient endothelial dysfunction in healthy men with no known risk factors for cardiovascular disease[88]. In another study on healthy subjects with no cardiovascular risk factors, a 3 minute mental stress task resulted in prolonged endothelial dysfunction[89]. Both studies provide evidence 
for a link between psychological stress and atherogenesis. Evidence shows that endothelial function also becomes impaired in depressed people[90]. Depression was associated with endothelial dysfunction in a study of 193 post-menopausal women[91]. Although the study finding is expressed in terms of the psychosocial trait of depression/anxiety, depression was measured using the Beck Depression Inventory and correlated with endothelial dysfunction. A similar finding of endothelial dysfunction was made in a study of antidepressant naïve depressed young adults diagnosed using Diagnostic and Statistical Manual IV criteria for MDD[92]. In patients who have suffered an acute coronary syndrome, those who are depressed have higher levels of cellular adhesion molecules such as ICAM-1[93]. Even in medically healthy patients, depressive illness leads to increased levels of ICAM-1, which predisposes to increased risk of $\mathrm{CHD}[80]$.

Depression has also been linked to increased risk of cardiac thrombotic events via platelet reactivity and activation[83]. Upon activation, platelets secrete serotonin, which acts on platelet serotonin receptors to promote aggregation on the platelets[94, 95] and causes vasoconstriction of arteries[12, 96]. Depressed patients show an upregulation of serotonin receptors on platelets, leading to increased density of platelet serotonin receptors[97, 98] and changes in platelet reactivity and activation[99-101]. Platelet activation can cause increased thrombosis, arterial occlusion and vasoconstriction[7]. Platelet activation likewise increases the levels of inflammatory cytokines[102]. Both endothelial dysfunction and platelet activation in depressed people contribute to atherosclerosis and vascular damage[85-87, 102], as well as abnormal brachial artery flow-mediated vasodilation[92]. Atherosclerosis is suggested as compromising cerebral blood supply, leading to damage and neuronal loss in brain 
regions involved in mood and cognition, resulting in major depression (this concept has been termed the vascular depression hypothesis) $[83,103]$.

These relationships are shown in Figure 4.

[Insert Figure 4 about here]

\section{Polyunsaturated Omega-3 Free Fatty Acid Deficiency}

Low serum and low red blood cell levels of omega-3 Polyunsaturated Fatty Acids (PUFAs) are associated with MDD in patients with CHD[104-106]. Omega-3 fatty acid deficiency is also associated with depression in the absence of other medical illness[107-112]. Conversely, eating foods containing PUFAs such as eicosapentaenoic acid (EPA) and docosahexaenoic acid (DHA) have been shown to reverse depression and enhance antidepressant efficacy[113-115]. Omega-3 fatty acid deficiency is separately associated with $\mathrm{CHD}[116]$. It has even been proposed that red blood cell EPA plus DHA be considered as an "Omega-3 Index" to predict risk for death from $\mathrm{CHD}[117]$.

PUFAs form constituents of cell membranes[118]. EPA and DHA in particular are found to be concentrated at neuronal synapses and are considered to play an important role in neurotransmission and receptor function in the human brain[116, $118,119]$. As such, this may represent a direct mechanism by which omega-3 PUFA deficiency causes MDD.

However, it has also been shown that major depression in acute coronary syndrome patients is associated with significantly lower plasma levels of omega 3 PUFAs[104]. Deficiency of these essential fatty acids could thus also represent a mechanism which links MDD and CHD[104]. There is evidence that a dietary deficiency of PUFAs is associated with an increased risk of inflammation[120] and 
that the effects of hypertensive, atherosclerotic and chronic inflammatory disorders may be exacerbated by inadequate intake of PUFAs[121]. The casual pathways by which PUFAs link CHD and MDD (Figure 5) may thus primarily involve inflammatory mechanisms and atherosclerosis.

\section{[Insert Figure 5 about here]}

\section{Autonomic Mechanisms}

Autonomic dysregulation, caused by depression, is thought to result in altered function of the sympathetic nervous system, activation of the hypothalamic-pituitaryadrenal axis, as well as parasympathetic changes, with irregularities of vagal control. This autonomic dysregulation has in turn been linked to an increased risk of cardiovascular disease[7].

People with depression have increased sympathetic activation (Esler et al 1982 - (5) below; Veith et al, 1994 (6) below), an increased resting heart rate, increased heart rate responses to physical stressors, impaired baroreflex sensitivity, high variability in ventricular repolarization, and reduced heart rate variability[122, 123]. These changes in turn have been associated with increased mortality and cardiac morbidity[124]. The causal pathways discussed below are summarised in Figure 6.

\section{The sympathetic nervous system}

People suffering from MDD can have increased activation of the sympathetic nervous system[125, 126]. Furthermore, sympathetic hyperactivity has been implicated in increased cardiovascular morbidity and mortality in people suffering from $\operatorname{MDD}[127$, 128]. Depressed people have been found to have increased levels of sympathetic tone as evidenced by elevated noradrenalin spillover[125, 126]. Activation of the cardiac sympathetic outflow occurs under conditions of experimental mental stress[129] and 
increased sympathetic outflow has also been associated with the severity of symptoms of depression during experimental mental stress[130-133]. Reaction to stress is generally characterised by an increase in sympathetic nerve activity, which results in physiological changes including increased cardiac output, heart rate and blood and increased muscular blood flow[134]. The increase in these physiological parameters is proposed to be a causal factor between emotional stress and adverse cardiovascular events[134].

Barton and colleagues[135] compared whole body sympathetic outflow with cardiac sympathetic outflow in people with MDD versus healthy controls. Participants with MDD as whole group did not display elevated sympathetic activity compared with the healthy control group. However, there was a bimodal distribution of cardiac and whole body sympathetic nerve activity in the participants with MDD, with one subgroup who displayed marked sympathetic activation and a subgroup with low sympathetic activity. Such findings allude to the underlying complexity of sympathetic regulation in $\mathrm{MDD}[135]$. Cardiac and total sympathetic activity in patients with MDD has been found to be elevated, while whereas muscle sympathetic activity is unchanged or reduced[135, 136]. Such findings support the finding that sympathetic nervous activity, at rest and in response to stressors, is regionalized[129]. The sympathetic outflow to organs such as the heart is preferentially activated, particularly during mental stress $[129,135]$ and this in turn is linked with a higher risk of $\mathrm{CHD}[127,128]$.

Sympathetic nervous activation has also been shown to occur in obesity and the metabolic syndrome[137]. While several mechanisms have been proposed to explain the primary etiology of obesity and obesity-related metabolic disturbances (reviewed in Lambert et al. [138]), sympathetic nervous activity has been shown to be 
elevated in obese persons[139, 140], and sympathetic outflow changes are considered to be a significant contributor to obesity and its related metabolic sequelae (Lambert et al. [138]). Obesity has been associated with increased urinary noradrenaline and normetanephrine levels[141, 142]. Obese people have also been shown to have increased efferent muscle sympathetic nerve activity[139, 140] as well as increased rates of noradrenergic spillover to the blood from the kidneys[143]. The effects of sympathetic activation in obese people have been linked to cardiovascular pathology such as CHD and cardiac failure via pathways such as hypertension and renal pathology (Lambert et al. [138]).

\section{The hypothalamic-pituitary-adrenal axis}

Depressed mood and stress can cause dysregulation of the HypothalamicPituitary-Adrenal (HPA) axis[22]. The HPA axis is the physiological system involved in response to stress[144]. This stress response is also known as the "fight or flight" response [145] or "general adaptation syndrome"[146].

It has been proposed that the general adaptational syndrome is governed by two systems, the corticotropin-releasing hormone $(\mathrm{CRH})$ system and the locus ceruleus-norepinephrine (LC-NE) (sympathetic) nervous system[147-149].

In response to a stressful stimulus, corticotropin-releasing hormone $(\mathrm{CRH})$ is released from hypothalamic neurons, triggering the secretion of adrenocorticotropic hormone (ACTH). ACTH in turn results in cortisol and catecholamine secretion, primarily of adrenaline, but also of noradrenaline. These secretory molecules complete a feedback loop by acting on the pituitary, hippocampus and hypothalamus to modulate further HPA activity. The sympathetic nervous system is also activated[149]. The result is the increase of circulating glucose, heart rate, and blood pressure[149]. 
The relationship between depression and HPA dysfunction was explored as early as the 1970 's, when dexamethasone testing was put forward as a diagnostic test for endogenous depression[150]. In healthy control subjects, dexamethasone administration causes decreased cortisol secretion in response to down-regulation of the HPA axis. However, up to $50 \%$ of adult depressed patients have no suppression of cortisol with administration of dexamethasone, due to glucocorticoid hypersecretion[151, 152]. Depressed people also have increased levels of corticotropin-releasing hormone $(\mathrm{CRH})$ in the cerebrospinal fluid, as well as in the paraventricular nucleus of the hypothalamus, supporting the hypothesis of an upregulation of the HPA axis in depression[153-156]. Intra-cerebroventricular administration of CRH in rat[157] and primate models[158] induced decreased levels of feeding and sexual activity, sleep disturbance and learning impairment, behaviours which have been suggested to imply depressed states in these animals.

Increased heart rate has been implicated in the increased risk of adverse cardiovascular events in depression via HPA axis dysregulation[124]. Corticotropinreleasing hormone increases sympathetic activity, which can result in increased mean heart rate[159] in patients with depression[160]. Carney et al.[161] showed that depressed patients with CHD exhibit higher mean heart rates than non-depressed patients with CHD. Increased mean heart rate has been shown to independently be a risk factor for increased coronary artery plaque rupture[162], providing a further mechanism for adverse cardiac events in depressed patients.

The increase in heart rate occurs in otherwise healthy depressed subjects, as well as those with co-morbid cardiac disease[163]. Elevated heart rate has been associated with arrhythmias and sudden death, as well as myocardial ischemia, and 
cardiac failure [161, 164-166]. In addition, increased heart rate causes increased arterial wall stress and is a risk factor for atherosclerosis[167].

There is also a relationship between elevated plasma cortisol and early atherosclerosis[168]. Chronic HPA and sympathoadrenal hyperactivity have also been linked to atherosclerosis[169]. These links may provide a further mechanism as to how increased plasma cortisol levels increase the risk of CVD. In addition, there is evidence that patients with Cushing's disease, who have increased cortisol levels, have an increased risk of cardiovascular disease[170]. Sympathetic hyperresponsiveness has also been linked to the development of myocardial ischemia during exercise and mental stress[171]. Krantz et al.[172] also showed that patients with CAD who had greater cardiovascular reactivity had higher rates of mental stressinduced myocardial ischemia.

The prefrontal cortex is intimately connected with the limbic system and is assumed to be involved in the modulation of autonomic responses to stress and emotional stimuli. Davydov et al.[122] suggested that the prefrontal cortex is part of the limbic system in terms of modulation of autonomic response. While such a classification might be controversial, there is evidence that the prefrontal cortex directly modulates cardiovascular control[173]. It is thus important in mood regulation and in cortical control of the HPA axis and the sympathetic nervous system. Depressed patients have been shown to have significant loss of cells in the prefrontal cortex[174]. This provides a possible mechanism for autonomic instability or dysfunction in people with depression.

Furthermore, hypothalamic-pituitary-adrenal axis dysfunction has been implicated in increasing the levels of pro-inflammatory cytokines[76, 175]. There is evidence that the autonomic nervous system may have an effect on the level of pro- 
inflammatory mediators in the body by modulating certain endocrine functions[176]. Adrenergic modulation by the sympathetic system and also the HPA axis can result in either the increased or decreased release of pro-inflammatory cytokines such as tumor necrosis factor (TNF) and interleukin 1 (IL1). Inflammatory cytokines, such as IL-6, may in turn further stimulate the HPA axis, which leads to the increased secretion of cortisol and other hormones[76, 175]. In addition, HPA axis dysfunction and reduced cardiac vagal control can result in reduced Heart Rate Variability (HRV)[177].

\section{Parasympathetic nervous system: Vagal mechanisms and heart rate variability.}

In humans, heart rate is not constant. It varies considerably, subject to the cardiovascular demands placed on it and the varied control mechanisms acting in a complex network of feedback loops[127, 178]. Heart rate variability (HRV) measures the beat-to-beat variations in heart rate, which naturally occurs in normal cardiac function. Heart rate variability is a key measure of the autonomic regulation of cardiac function and "healthy" or normal cardiac function is determined by these feedback loops acting on the heart[127, 179]. The small delays in each feedback loop cumulatively result in complex oscillations in heart rate which are measurable by beat-by-beat time series[169]. This produces a complex non-linear variation of heart rate. HRV has been linked to cardiovascular health outcomes[178]. It has been suggested that poor health is associated with a loss of complexity and a correlation exists between severity of illness or dysfunction and magnitude of loss of complexity in cardiac control. Depression and CHD are theorised to disrupt autonomic control feedback loops causing a reduction in HRV[127]. HRV is thus a key method for exploring directly the vagal (parasympathetic) influence of the brain on the heart and 
vice versa, which may provide a strong and direct neurological mechanism linking depression and CHD.

Parasympathetic cardiac control is the principal mechanism for autonomic regulation of cardiac function[180] and is mediated by the vagus nerve[181]. Changes in vagal tone have been linked to both depression and cardiac disease[180]. The control of physiological cardiac parameters such as heart rate are hypothesised as being the result of a dynamic equilibrium between opposing sympathetic and parasympathetic (vagal) influences[182]. This dynamic equilibrium, which also results in HRV, is thought to occur due to co-activation or co-inhibition of the sympathetic and parasympathetic nervous systems, or an activation of one with an inhibition of the other [182]. However, vagal tone is thought to provide overall control of the equilibrium by acting as a "brake", counteracting and damping sympathetic drive, resulting in the term Cardiac Vagal Control (CVC) to refer to the balance of both sympathetic and parasympathetic control elements[180]. The level of resting vagal tone is linked to physiological responses to stressful situations. High baseline levels of cardiac CVC allows appropriate regulation of sympathetic and parasympathetic balance. Weak parasympathetic control in turn may be linked to poor balance of parasympathetic and sympathetic control[180].

Depression can cause reduced cardiac vagal control[180]. Reduced HRV may in itself present a further mechanism relating depression and CHD, as $\mathrm{HRV}$ is a known risk factor for sudden death and ventricular arrhythmias in patients with CHD[183-185]. Early HRV changes have been shown to occur following myocardial infarction (MI) and have been linked prognostically to mortality risk[186-191]. The relative risk of mortality after acute myocardial infarction is significantly higher in patients with decreased HRV $[188,192]$. A decline in HRV increases the risk of 
myocardial infarction and coronary insufficiency[185], increases the relative risk of death from cardiovascular disease[193, 194] and increases the risk for sudden cardiac death[195, 196]. It should be noted, however, that low HRV has also been associated with increased risk of death in individuals without hypertension, diabetes, cancer, or symptomatic heart disease[193].

Finally, it has been suggested that there may be evidence for a causal relationship between CVC and depression and that CVC may be involved in depression maintenance[180].

\section{The Relationship between Major Depression and Coronary Heart Disease: A “Causal Network".}

From the review of the literature, it is evident that there are several possible mechanisms responsible for the observed relationship between depression and cardiac disease. They are often presented as separate entities in the literature[17, 20]. However, it is conceivable that no one mechanism stands alone as a cause for the relationship. In fact, the causal mechanisms described in this review are linked and function in concert, rather than a group of isolated pathways linking depression and ischaemic cardiac disease. There are thus considerable inter-relationships between mechanisms and even the possibility of feedback loops between pathways. This suggests that the mechanisms might form a "Causal Network", which describes the relationship between MDD and CHD. This Causal Network thus describes all the linked mechanisms connecting MDD and CHD, conceptualising them as a single interconnected system. A diagram of the proposed Causal Network, based on current evidence, is shown in Figure 7.

\section{[Insert Figure 7 about here]}


Barth et al.[17] described cytokine, endothelial and autonomic nervous system mediated pathways as "direct" pathways between MDD and CHD. The authors then describe behavioural mechanisms, such as the increase in classic coronary risk factors with depression leading to coronary heart disease, as "indirect" pathways. However the overall synergistic effect of multiple interrelated pathways linking cardiac disease and depression may mean that no single pathway is solely "direct". Additionally, behavioural factors such as smoking may feed directly into the causal network by accelerating processes such as atherosclerosis[197], further blurring what is considered a "direct" and "indirect" pathway.

Having described how MDD and CHD are linked by a network of causal pathways, how does this concept further promote understanding of the complex interrelationship between these two disease entities? The Causal Network is best conceptualised as a biological network. As such, it is amenable to further study within the framework of systems biology[19]. In order to establish how systems biology can be applied to the Causal Network, a brief introduction to systems biology itself is required.

\section{Discussion: The Application of Network Theory to the Causal Network linking Major Depression and Coronary Heart Disease}

Systems Biology, which encompasses Network Theory and its methodological approaches, has shown great promise, offering new tools to analyse and understand complex biological systems. Systems biology involves an integrated analysis of interacting biological pathways or networks [198]. Large numbers of individual elements (such as bio-molecules) or even biological sub-systems, are measured simultaneously over time and their relationships to each other are elucidated. 
Complex networks occur widely, with common examples including societal and social networks[199, 200], co-authorship of scientific papers[201, 202], and the internet[203, 204]. Biological systems in particular are amenable to elucidation using network theory, with examples ranging from networks of biochemical interactions or gene networks[199, 205], protein and enzymatic networks[199, 206], through to metabolic pathways[205] and food webs in ecology[207, 208]. The principles of biological networks also apply to disease mechanisms. Noorbakhsh et al.[198] have argued that systems biology methodology has immediate application in understanding complex diseases which involve multiple pathogenic determinants. The authors make this point in the context of neurodegenerative diseases such as Alzheimer's disease[198]. It is equally applicable to the multiple and complex pathogenic determinants linking CHD and Major Depression. It is thus proposed that the Causal Network underlying CHD and Major Depression is amenable to analysis using the paradigm of Systems Biology.

There have been proposals to map, understand, and model, in quantifiable terms, the topological and dynamic properties of various biological networks, for example those that control the behaviour of living cells[209]. Alm and Arkin[199] have suggested that network topology data can be used to generate new hypotheses about how systems are organised. By further studying how the various pathways which link CHD to depression are interconnected with each other, understanding could be reached on how to reduce the risk of recurrent cardiac events in depressed CHD patients, for example.

\section{Establishing the topology of the network}

By conceptualising the Causal Network as a biological network, it follows that the topology of this network needs to be ascertained. Figure 7 represents an initial 
attempt to provide a topological map of the causal pathways linking MDD and CHD. Applying the paradigm of systems biology would allow the use of several tools to establish in detail the topology or overall structural organization of the Causal Network. Specific measures such as network degree, degree distribution and the clustering coefficient[209] could be used to characterise the Causal Network.

Future work should assess whether the Causal Network has characteristics of a modular network (in which each node should have about the same number of links), a scale-free network (in which most pathways are linked through a few highly connected 'hubs') or a hierarchical network, which has characteristics of both scalefree and modular networks[199, 210]. If, for example, the Causal Network has properties of a scale-free network, it means that certain nodes are highly connected and thus critical to the causal relationship between MDD and CHD. For instance, inflammatory cytokines (see Figure 6) might represent such a highly connected hub in the relationship between CHD and MDD. This might mean that by focusing clinical prevention or treatment on this mechanism, such treatment or prevention may be more effective.

\section{Quantification of the Causal Network}

The emergent properties of a biological system (or network) generally cannot be inferred from the characteristics of isolated components or pathways of that system. Systems Biology relies on large-scale quantification of biological systems, with subsequent integration of the quantified data, which allows the development of accurate models of the system[198]. Such models provide information not only on the architecture of a given network, but also on the dynamics of the network (i.e., how information, energy or other elements flow through a given network). Each mechanism linking Major Depression and CHD can be conceptualised as a node in a 
Causal Network. Attempting to quantify each node will lead to an understanding of which nodes contribute more, or less (in quantitative terms), to exacerbating cardiac disease in depressed patients, or causing depression in patients post MI. Despite being interrelated, it is not clear how much each mechanism may contribute to the overall relationship between MDD and CVD in quantitative terms. If quantitative relationships can be established between each pathway, and between measures of depression and cardiac outcomes, potentially the contribution of each mechanism or pathway can be measured and ranked.

\section{Conclusions and Recommendations}

This review has described several mechanisms which have been put forward as causes for the link between Major Depression and CHD. Behavioural mechanisms, genetic mechanisms, dysregulation of immune mechanisms, coagulation, Omega-3 PUFA deficiency, as well as vascular endothelial abnormalities and autonomic mechanisms, have previously been discussed as separate entities in the literature. However, the considerable overlap and inter-connectivity between them suggests that they form a Causal Network which links MDD and CHD. Viewing these causal mechanisms as an interdependent network, which is amenable to analysis using a Systems Biology approach, presents a new paradigm in this field and provides fertile ground for further research. The initial network model presented in this review is incomplete and presents a starting point. Further research is required to establish all the nodes and links in the network (i.e. further mechanisms which may link CHD and depressive illness, as well as further links between them). However, the following recommendations are hoped to guide further research in this field: 
1. More research is needed to further the complete characterisation of the Causal Network linking MDD and CHD, allowing identification of all the interlinked mechanisms connecting the two diseases.

2. The establishment of the topology of the Causal Network will allow the most accurate description (and subsequent modelling) how all the mechanisms relate to each other in terms of network theory.

3. The quantification of activity between each node of the network, along with a model of the network topology, will allow the identification of the most significant nodes in the causal network.

4. Since these significant nodes will correspond to a specific metabolic or disease process (e.g., the increased release of inflammatory cytokines), these nodes or processes can be specifically targeted to yield an efficient means of disease prevention of treatment. It is likely that if a key node in the network is targeted effectively, this intervention may have a significant effect on both MDD and cardiac risk in patients.

Adopting a Systems Biology paradigm would allow analysis using techniques which already exist to qualitatively and quantitatively analyse biological networks and would provide fertile ground for further research. 


\section{References}

1. Vos T, Mathers CD. The burden of mental disorders: a comparison of methods between the Australian burden of disease studies and the Global Burden of Disease study. Bull World Health Organ 2000; 78:427-38.

2. Moussavi S, Chatterji S, Verdes E, Tandon A, Patel V, Ustun B. Depression, chronic diseases, and decrements in health: results from the World Health Surveys. Lancet 2007; 370:851-8.

3. World Health Organization. The Global Burden of Disease, 2004 Update. Switzerland: WHO Press, 2008.

4. Carney RM, Rich MW, Freedland KE, Saini J, teVelde A, Simeone C, Clark K. Major depressive disorder predicts cardiac events in patients with coronary artery disease. Psychosom Med 1988; 50:627-33.

5. Frasure-Smith N, Lesperance F, Talajic M. Depression following myocardial infarction. Impact on 6-month survival. JAMA 1993; 270:1819-25.

6. Kawachi I, Colditz GA, Ascherio A, Rimm EB, Giovannucci E, Stampfer MJ, Willett WC. Prospective study of phobic anxiety and risk of coronary heart disease in men. Circulation 1994; 89:1992-7.

7. Musselman DL, Evans DL, Nemeroff CB. The relationship of depression to cardiovascular disease: epidemiology, biology, and treatment. Arch Gen Psychiatry 1998; 55:580-92.

8. Rugulies R. Depression as a predictor for coronary heart disease. a review and meta-analysis. Am J Prev Med 2002; 23:51-61.

9. Wulsin LR, Singal BM. Do depressive symptoms increase the risk for the onset of coronary disease? A systematic quantitative review. Psychosom Med 2003; 65:201-10.

10. Goldston K, Baillie AJ. Depression and coronary heart disease: a review of the epidemiological evidence, explanatory mechanisms and management approaches. Clin Psychol Rev 2008; 28:288-306.

11. Seymour J, Benning TB. Depression, cardiac mortality and all-cause mortality. Advances in Psychiatric Treatment 2009; 15:107-113.

12. Schulman J, Shapiro P. Depression and Cardiovascular Disease: What is the Correlation. Psychiatric Times 2008; 25.

13. Penninx BW, Beekman AT, Honig A, Deeg DJ, Schoevers RA, van Eijk JT, van Tilburg W. Depression and cardiac mortality: results from a community-based longitudinal study. Arch Gen Psychiatry 2001; 58:221-7.

14. Lesperance F, Frasure-Smith N, Talajic M, Bourassa MG. Five-year risk of cardiac mortality in relation to initial severity and one-year changes in depression symptoms after myocardial infarction. Circulation 2002; 105:1049-53.

15. Rozanski A, Blumenthal JA, Kaplan J. Impact of psychological factors on the pathogenesis of cardiovascular disease and implications for therapy. Circulation 1999; 99:2192-217.

16. Thombs BD, Bass EB, Ford DE, Stewart KJ, Tsilidis KK, Patel U, Fauerbach JA, Bush DE, Ziegelstein RC. Prevalence of depression in survivors of acute myocardial infarction. J Gen Intern Med 2006; 21:30-8. 
17. Barth J, Schumacher M, Herrmann-Lingen C. Depression as a risk factor for mortality in patients with coronary heart disease: a meta-analysis. Psychosom Med 2004; 66:802-13.

18. Tracey KJ. The inflammatory reflex. Nature 2002; 420:853-9.

19. de Jonge P, Rosmalen JG, Kema IP, Doornbos B, van Melle JP, Pouwer F, Kupper N. Psychophysiological biomarkers explaining the association between depression and prognosis in coronary artery patients: A critical review of the literature. Neurosci Biobehav Rev 2009.

20. Carney RM, Freedland KE, Miller GE, Jaffe AS. Depression as a risk factor for cardiac mortality and morbidity: a review of potential mechanisms. $J$ Psychosom Res 2002; 53:897-902.

21. Pacher P, Kecskemeti V. Cardiovascular side effects of new antidepressants and antipsychotics: new drugs, old concerns? Curr Pharm Des 2004; 10:2463-75.

22. Schulman J, Muskin P, Shapiro P. Psychiatry and Cardiovascular Disease. Focus 2005; 3:208-224.

23. Kawakami N, Takatsuka N, Shimizu H, Ishibashi H. Depressive symptoms and occurrence of type 2 diabetes among Japanese men. Diabetes Care 1999; 22:1071-6.

24. Golden SH, Williams JE, Ford DE, Yeh HC, Paton Sanford C, Nieto FJ, Brancati FL. Depressive symptoms and the risk of type 2 diabetes: the Atherosclerosis Risk in Communities study. Diabetes Care 2004; 27:429-35.

25. Arroyo C, Hu FB, Ryan LM, Kawachi I, Colditz GA, Speizer FE, Manson J. Depressive symptoms and risk of type 2 diabetes in women. Diabetes Care 2004; 27:129-33.

26. Garcia MJ, McNamara PM, Gordon T, Kannel WB. Morbidity and mortality in diabetics in the Framingham population. Sixteen year follow-up study. Diabetes 1974; 23:105-11.

27. Pine DS, Goldstein RB, Wolk S, Weissman MM. The association between childhood depression and adulthood body mass index. Pediatrics 2001; 107:1049-56.

28. Goodman E, Whitaker RC. A prospective study of the role of depression in the development and persistence of adolescent obesity. Pediatrics 2002; 110:497504.

29. Vogelzangs N, Kritchevsky SB, Beekman AT, Newman AB, Satterfield S, Simonsick EM, Yaffe K, Harris TB, Penninx BW. Depressive symptoms and change in abdominal obesity in older persons. Arch Gen Psychiatry 2008; 65:1386-93.

30. Luppino FS, de Wit LM, Bouvy PF, Stijnen T, Cuijpers P, Penninx BW, Zitman FG. Overweight, obesity, and depression: a systematic review and metaanalysis of longitudinal studies. Arch Gen Psychiatry 2010; 67:220-9.

31. Everson-Rose SA, Meyer PM, Powell LH, Pandey D, Torrens JI, Kravitz HM, Bromberger JT, Matthews KA. Depressive symptoms, insulin resistance, and risk of diabetes in women at midlife. Diabetes Care 2004; 27:2856-62.

32. Skilton MR, Moulin P, Terra JL, Bonnet F. Associations between anxiety, depression, and the metabolic syndrome. Biol Psychiatry 2007; 62:1251-7.

33. Malik S, Wong ND, Franklin SS, Kamath TV, L'Italien GJ, Pio JR, Williams GR. Impact of the metabolic syndrome on mortality from coronary heart disease, cardiovascular disease, and all causes in United States adults. Circulation 2004; 110:1245-50. 
34. Dekker JM, Girman C, Rhodes T, Nijpels G, Stehouwer CD, Bouter LM, Heine RJ. Metabolic syndrome and 10-year cardiovascular disease risk in the Hoorn Study. Circulation 2005; 112:666-73.

35. Ford ES. Risks for all-cause mortality, cardiovascular disease, and diabetes associated with the metabolic syndrome: a summary of the evidence. Diabetes Care 2005; 28:1769-78.

36. Kaplan G, Keil JE. Socioeconomic factors and cardiovascular disease: a review of the literature. Circulation 1993; 88:1973-98.

37. Tennant C. Life stress, social support and coronary heart disease. Aust $N Z J$ Psychiatry 1999; 33:636-41.

38. Segrin C. Social skills deficits associated with depression. Clin Psychol Rev 2000; 20:379-403.

39. DiMatteo MR, Lepper HS, Croghan TW. Depression is a risk factor for noncompliance with medical treatment: meta-analysis of the effects of anxiety and depression on patient adherence. Arch Intern Med 2000; 160:2101-7.

40. Ziegelstein RC, Fauerbach JA, Stevens SS, Romanelli J, Richter DP, Bush DE. Patients with depression are less likely to follow recommendations to reduce cardiac risk during recovery from a myocardial infarction. Arch Intern Med 2000; 160:1818-23.

41. House JS, Robbins C, Metzner HL. The association of social relationships and activities with mortality: prospective evidence from the Tecumseh Community Health Study. Am J Epidemiol 1982; 116:123-40.

42. Berkman LF, Leo-Summers L, Horwitz RI. Emotional support and survival after myocardial infarction. A prospective, population-based study of the elderly. Ann Intern Med 1992; 117:1003-9.

43. Frasure-Smith N, Lesperance F, Gravel G, Masson A, Juneau M, Talajic M, Bourassa MG. Social support, depression, and mortality during the first year after myocardial infarction. Circulation 2000; 101:1919-24.

44. Joutsenniemi K, Martelin T, Martikainen P, Pirkola S, Koskinen S. Living arrangements and mental health in Finland. J Epidemiol Community Health 2006; 60:468-75.

45. Brown MA, Munford AM, Munford PR. Behavior therapy of psychological distress in patients after myocardial infarction or coronary bypass. $J$ Cardiopulmonary Rehabil 1993; 13:201-210.

46. Stern MJ, Pascale L, Ackerman A. Life adjustment postmyocardial infarction: determining predictive variables. Arch Intern Med 1977; 137:1680-5.

47. Breslau N, Peterson EL, Schultz LR, Chilcoat HD, Andreski P. Major depression and stages of smoking. A longitudinal investigation. Arch Gen Psychiatry 1998; 55:161-6.

48. Fergusson DM, Goodwin RD, Horwood LJ. Major depression and cigarette smoking: results of a 21-year longitudinal study. Psychol Med 2003; 33:135767.

49. John U, Meyer C, Rumpf HJ, Hapke U. Self-efficacy to refrain from smoking predicted by major depression and nicotine dependence. Addict Behav 2004; 29:857-66.

50. Anda, Williamson DF, Escobedo LG, Mast EE, Giovino GA, Remington PL. Depression and the dynamics of smoking. A national perspective. JAMA 1990; 264:1541-5.

51. Hall SM, Munoz RF, Reus VI, Sees KL. Nicotine, negative affect, and depression. J Consult Clin Psychol 1993; 61:761-7. 
52. Quattrocki E, Baird A, Yurgelun-Todd D. Biological aspects of the link between smoking and depression. Harv Rev Psychiatry 2000; 8:99-110.

53. Yusuf S, Hawken S, Ounpuu S, Dans T, Avezum A, Lanas F, McQueen M, Budaj A, Pais P, Varigos J, Lisheng L. Effect of potentially modifiable risk factors associated with myocardial infarction in 52 countries (the INTERHEART study): case-control study. Lancet 2004; 364:937-52.

54. McCaffery JM, Duan QL, Frasure-Smith N, Barhdadi A, Lesperance F, Theroux P, Rouleau GA, Dube MP. Genetic predictors of depressive symptoms in cardiac patients. Am J Med Genet B Neuropsychiatr Genet 2009; 150B:381-8.

55. Owens MJ, Nemeroff CB. Role of serotonin in the pathophysiology of depression: focus on the serotonin transporter. Clin Chem 1994; 40:288-95.

56. Furlong RA, Ho L, Walsh C, Rubinsztein JS, Jain S, Paykel ES, Easton DF, Rubinsztein DC. Analysis and meta-analysis of two serotonin transporter gene polymorphisms in bipolar and unipolar affective disorders. Am J Med Genet 1998; 81:58-63.

57. Ogilvie AD, Battersby S, Bubb VJ, Fink G, Harmar AJ, Goodwim GM, Smith CA. Polymorphism in serotonin transporter gene associated with susceptibility to major depression. Lancet 1996; 347:731-3.

58. Caspi A, Sugden K, Moffitt TE, Taylor A, Craig IW, Harrington H, McClay J, Mill J, Martin J, Braithwaite A, Poulton R. Influence of life stress on depression: moderation by a polymorphism in the 5-HTT gene. Science 2003; 301:386-9.

59. Jacobs N, Kenis G, Peeters F, Derom C, Vlietinck R, van Os J. Stress-related negative affectivity and genetically altered serotonin transporter function: evidence of synergism in shaping risk of depression. Arch Gen Psychiatry 2006; 63:989-96.

60. Eley TC, Sugden K, Corsico A, Gregory AM, Sham P, McGuffin P, Plomin R, Craig IW. Gene-environment interaction analysis of serotonin system markers with adolescent depression. Mol Psychiatry 2004; 9:908-15.

61. Wilhelm K, Mitchell PB, Niven H, Finch A, Wedgwood L, Scimone A, Blair IP, Parker G, Schofield PR. Life events, first depression onset and the serotonin transporter gene. Br J Psychiatry 2006; 188:210-5.

62. Hoefgen B, Schulze TG, Ohlraun S, von Widdern O, Hofels S, Gross M, Heidmann V, Kovalenko S, Eckermann A, Kolsch H, Metten M, Zobel A, Becker T, Nothen MM, Propping P, Heun R, Maier W, Rietschel M. The power of sample size and homogenous sampling: association between the 5HTTLPR serotonin transporter polymorphism and major depressive disorder. Biol Psychiatry 2005; 57:247-51.

63. Kendler KS, Kuhn JW, Vittum J, Prescott CA, Riley B. The interaction of stressful life events and a serotonin transporter polymorphism in the prediction of episodes of major depression: a replication. Arch Gen Psychiatry 2005; 62:529-35.

64. Kaufman J, Yang BZ, Douglas-Palumberi H, Houshyar S, Lipschitz D, Krystal $\mathrm{JH}$, Gelernter J. Social supports and serotonin transporter gene moderate depression in maltreated children. Proc Natl Acad Sci U S A 2004; 101:1731621.

65. Zalsman G, Huang YY, Oquendo MA, Burke AK, Hu XZ, Brent DA, Ellis SP, Goldman D, Mann JJ. Association of a triallelic serotonin transporter gene promoter region (5-HTTLPR) polymorphism with stressful life events and severity of depression. Am J Psychiatry 2006; 163:1588-93. 
66. Otte C, McCaffery J, Ali S, Whooley MA. Association of a serotonin transporter polymorphism (5-HTTLPR) with depression, perceived stress, and norepinephrine in patients with coronary disease: the Heart and Soul Study. Am J Psychiatry 2007; 164:1379-84.

67. Nakatani D, Sato H, Sakata Y, Shiotani I, Kinjo K, Mizuno H, Shimizu M, Ito H, Koretsune Y, Hirayama A, Hori M. Influence of serotonin transporter gene polymorphism on depressive symptoms and new cardiac events after acute myocardial infarction. Am Heart J 2005; 150:652-8.

68. Ramamoorthy S, Bauman AL, Moore KR, Han H, Yang-Feng T, Chang AS, Ganapathy V, Blakely RD. Antidepressant- and cocaine-sensitive human serotonin transporter: molecular cloning, expression, and chromosomal localization. Proc Natl Acad Sci U S A 1993; 90:2542-6.

69. Hoffman BJ, Mezey E, Brownstein MJ. Cloning of a serotonin transporter affected by antidepressants. Science 1991; 254:579-80.

70. Ramasubbu R. Serotonin transporter gene functional polymorphism: a plausible candidate gene for increased vascular risk in depression. Med Hypotheses 2003; 61:36-44.

71. Danesh J, Whincup P, Walker M, Lennon L, Thomson A, Appleby P, Gallimore JR, Pepys MB. Low grade inflammation and coronary heart disease: prospective study and updated meta-analyses. BMJ 2000; 321:199-204.

72. Appels A, Bar FW, Bar J, Bruggeman C, de Baets M. Inflammation, depressive symptomtology, and coronary artery disease. Psychosom Med 2000; 62:601-5.

73. Kiecolt-Glaser JK, Glaser R. Depression and immune function: central pathways to morbidity and mortality. J Psychosom Res 2002; 53:873-6.

74. Maes M, Meltzer HY, Bosmans E, Bergmans R, Vandoolaeghe E, Ranjan R, Desnyder R. Increased plasma concentrations of interleukin-6, soluble interleukin-6, soluble interleukin-2 and transferrin receptor in major depression. J Affect Disord 1995; 34:301-9.

75. Mikova O, Yakimova R, Bosmans E, Kenis G, Maes M. Increased serum tumor necrosis factor alpha concentrations in major depression and multiple sclerosis. Eur Neuropsychopharmacol 2001; 11:203-8.

76. Miller GE, Stetler CA, Carney RM, Freedland KE, Banks WA. Clinical depression and inflammatory risk markers for coronary heart disease. Am J Cardiol 2002; 90:1279-83.

77. Bremmer MA, Beekman AT, Deeg DJ, Penninx BW, Dik MG, Hack CE, Hoogendijk WJ. Inflammatory markers in late-life depression: results from a population-based study. J Affect Disord 2008; 106:249-55.

78. Blum A, Miller H. Pathophysiological role of cytokines in congestive heart failure. Annu Rev Med 2001; 52:15-27.

79. Alonso-Martinez JL, Llorente-Diez B, Echegaray-Agara M, Olaz-Preciado F, Urbieta-Echezarreta M, Gonzalez-Arencibia C. C-reactive protein as a predictor of improvement and readmission in heart failure. Eur J Heart Fail 2002; 4:331-6.

80. Empana JP, Sykes DH, Luc G, Juhan-Vague I, Arveiler D, Ferrieres J, Amouyel P, Bingham A, Montaye M, Ruidavets JB, Haas B, Evans A, Jouven X, Ducimetiere $\mathrm{P}$. Contributions of depressive mood and circulating inflammatory markers to coronary heart disease in healthy European men: the Prospective Epidemiological Study of Myocardial Infarction (PRIME). Circulation 2005; 111:2299-305. 
81. Tousoulis D, Davies G, Stefanadis C, Toutouzas P, Ambrose JA. Inflammatory and thrombotic mechanisms in coronary atherosclerosis. Heart 2003; 89:9937.

82. Dantzer R, Wollman EE, Yirmiya R. Cytokines and depression: an update. Brain Behav Immun 2002; 16:501-2.

83. Frasure-Smith N, Lesperance F. Reflections on depression as a cardiac risk factor. Psychosom Med 2005; 67 Suppl 1:S19-25.

84. Schins A, Tulner D, Lousberg R, Kenis G, Delanghe J, Crijns HJ, Grauls G, Stassen F, Maes M, Honig A. Inflammatory markers in depressed postmyocardial infarction patients. J Psychiatr Res 2005; 39:137-44.

85. Laghrissi-Thode F, Wagner WR, Pollock BG, Johnson PC, Finkel MS. Elevated platelet factor 4 and beta-thromboglobulin plasma levels in depressed patients with ischemic heart disease. Biol Psychiatry 1997; 42:290-5.

86. Nemeroff CB, Musselman DL. Are platelets the link between depression and ischemic heart disease? Am Heart J 2000; 140:57-62.

87. O'Connor CM, Gurbel PA, Serebruany VL. Depression and ischemic heart disease. Am Heart J 2000; 140:63-9.

88. Ghiadoni L, Donald AE, Cropley M, Mullen MJ, Oakley G, Taylor M, O'Connor G, Betteridge J, Klein N, Steptoe A, Deanfield JE. Mental stress induces transient endothelial dysfunction in humans. Circulation 2000; 102:2473-8.

89. Spieker LE, Hurlimann D, Ruschitzka F, Corti R, Enseleit F, Shaw S, Hayoz D, Deanfield JE, Luscher TF, Noll G. Mental stress induces prolonged endothelial dysfunction via endothelin-A receptors. Circulation 2002; 105:2817-20.

90. Broadley AJ, Korszun A, Jones CJ, Frenneaux MP. Arterial endothelial function is impaired in treated depression. Heart 2002; 88:521-3.

91. Harris KF, Matthews KA, Sutton-Tyrrell K, Kuller LH. Associations between psychological traits and endothelial function in postmenopausal women. Psychosom Med 2003; 65:402-9.

92. Rajagopalan S, Brook R, Rubenfire M, Pitt E, Young E, Pitt B. Abnormal brachial artery flow-mediated vasodilation in young adults with major depression. $\mathrm{Am}$ J Cardiol 2001; 88:196-8, A7.

93. Lesperance F, Frasure-Smith N, Theroux P, Irwin M. The association between major depression and levels of soluble intercellular adhesion molecule 1, interleukin-6, and C-reactive protein in patients with recent acute coronary syndromes. Am J Psychiatry 2004; 161:271-7.

94. Dale GL, Friese P, Batar P, Hamilton SF, Reed GL, Jackson KW, Clemetson KJ, Alberio L. Stimulated platelets use serotonin to enhance their retention of procoagulant proteins on the cell surface. Nature 2002; 415:175-9.

95. De Clerck F. Effects of serotonin on platelets and blood vessels. J Cardiovasc Pharmacol 1991; 17 Suppl 5:S1-5.

96. Weyrich AS, Solis GA, Li KS, Tulenko TN, Santamore WP. Platelet amplification of vasospasm. Am J Physiol 1992; 263:H349-58.

97. Arora RC, Meltzer HY. Increased serotonin2 (5-HT2) receptor binding as measured by $3 \mathrm{H}$-lysergic acid diethylamide (3H-LSD) in the blood platelets of depressed patients. Life Sci 1989; 44:725-34.

98. Sheline YI, Bardgett ME, Jackson JL, Newcomer JW, Csernansky JG. Platelet serotonin markers and depressive symptomatology. Biol Psychiatry 1995; 37:442-7. 
99. Shimbo D, Child J, Davidson K, Geer E, Osende JI, Reddy S, Dronge A, Fuster V, Badimon JJ. Exaggerated serotonin-mediated platelet reactivity as a possible link in depression and acute coronary syndromes. Am J Cardiol 2002; 89:331-3.

100. Cerrito F, Lazzaro MP, Gaudio E, Arminio P, Aloisi G. 5HT2-receptors and serotonin release: their role in human platelet aggregation. Life Sci 1993; 53:209-15.

101. Nemeroff CB, Knight DL, Franks J, Craighead WE, Krishnan KR. Further studies on platelet serotonin transporter binding in depression. $\mathrm{Am} J$ Psychiatry 1994; 151:1623-5.

102. Vieweg WV, Julius DA, Fernandez A, Wulsin LR, Mohanty PK, Beatty-Brooks M, Hasnain M, Pandurangi AK. Treatment of depression in patients with coronary heart disease. Am J Med 2006; 119:567-73.

103. Alexopoulos GS, Meyers BS, Young RC, Campbell S, Silbersweig D, Charlson M. 'Vascular depression' hypothesis. Arch Gen Psychiatry 1997; 54:915-22.

104. Frasure-Smith N, Lesperance F, Julien P. Major depression is associated with lower omega-3 fatty acid levels in patients with recent acute coronary syndromes. Biol Psychiatry 2004; 55:891-6.

105. Amin AA, Menon RA, Reid KJ, Harris WS, Spertus JA. Acute coronary syndrome patients with depression have low blood cell membrane omega-3 fatty acid levels. Psychosom Med 2008; 70:856-62.

106. Parker G, Gibson NA, Brotchie H, Heruc G, Rees AM, Hadzi-Pavlovic D. Omega-3 fatty acids and mood disorders. Am J Psychiatry 2006; 163:969-78.

107. Hibbeln JR. Fish consumption and major depression. Lancet 1998; 351:1213.

108. Hibbeln JR, Salem N, Jr. Dietary polyunsaturated fatty acids and depression: when cholesterol does not satisfy. Am J Clin Nutr 1995; 62:1-9.

109. Horrobin DF. A new category of psychotropic drugs: neuroactive lipids as exemplified by ethyl eicosapentaenoate (E-E). Prog Drug Res 2002; 59:17199.

110. Locke CA, Stoll AL. Omega-3 fatty acids in major depression. World Rev Nutr Diet 2001; 89:173-85.

111. Maes M, Smith R, Christophe A, Cosyns P, Desnyder R, Meltzer H. Fatty acid composition in major depression: decreased omega 3 fractions in cholesteryl esters and increased C20: 4 omega 6/C20:5 omega 3 ratio in cholesteryl esters and phospholipids. J Affect Disord 1996; 38:35-46.

112. Sontrop J, Campbell MK. Omega-3 polyunsaturated fatty acids and depression: a review of the evidence and a methodological critique. Prev Med 2006; 42:413.

113. Lin PY, Su KP. A meta-analytic review of double-blind, placebo-controlled trials of antidepressant efficacy of omega-3 fatty acids. J Clin Psychiatry 2007; 68:1056-61.

114. Nemets B, Stahl Z, Belmaker RH. Addition of omega-3 fatty acid to maintenance medication treatment for recurrent unipolar depressive disorder. Am J Psychiatry 2002; 159:477-9.

115. Peet M, Horrobin DF. A dose-ranging study of the effects of ethyleicosapentaenoate in patients with ongoing depression despite apparently adequate treatment with standard drugs. Arch Gen Psychiatry 2002; 59:913-9.

116. Kris-Etherton PM, Harris WS, Appel LJ. Fish consumption, fish oil, omega-3 fatty acids, and cardiovascular disease. Circulation 2002; 106:2747-57. 
117. Harris WS, Von Schacky C. The Omega-3 Index: a new risk factor for death from coronary heart disease? Prev Med 2004; 39:212-20.

118. Bruinsma KA, Taren DL. Dieting, essential fatty acid intake, and depression. Nutr Rev 2000; 58:98-108.

119. Haag M. Essential fatty acids and the brain. Can J Psychiatry 2003; 48:195-203.

120. Iso H, Sato S, Umemura U, Kudo M, Koike K, Kitamura A, Imano H, Okamura T, Naito Y, Shimamoto T. Linoleic acid, other fatty acids, and the risk of stroke. Stroke 2002; 33:2086-93.

121. Simopoulos AP. Omega-3 fatty acids in inflammation and autoimmune diseases. $J$ Am Coll Nutr 2002; 21:495-505.

122. Davydov DM, Shapiro D, Cook IA, Goldstein I. Baroreflex mechanisms in major depression. Prog Neuropsychopharmacol Biol Psychiatry 2007; 31:16477.

123. De Meersman RE, Stein PK. Vagal modulation and aging. Biol Psychol 2007; 74:165-73.

124. Grippo AJ, Johnson AK. Biological mechanisms in the relationship between depression and heart disease. Neurosci Biobehav Rev 2002; 26:941-62.

125. Esler M, Turbott J, Schwarz R, Leonard P, Bobik A, Skews H, Jackman G. The peripheral kinetics of norepinephrine in depressive illness. Arch Gen Psychiatry 1982; 39:295-300.

126. Veith RC, Lewis N, Linares OA, Barnes RF, Raskind MA, Villacres EC, Murburg MM, Ashleigh EA, Castillo S, Peskind ER, et al. Sympathetic nervous system activity in major depression. Basal and desipramine-induced alterations in plasma norepinephrine kinetics. Arch Gen Psychiatry 1994; $51: 411-22$.

127. Carney RM, Saunders RD, Freedland KE, Stein P, Rich MW, Jaffe AS. Association of depression with reduced heart rate variability in coronary artery disease. Am J Cardiol 1995; 76:562-4.

128. Sloan RP, Shapiro PA, Bagiella E, Myers MM, Gorman JM. Cardiac autonomic control buffers blood pressure variability responses to challenge: a psychophysiologic model of coronary artery disease. Psychosom Med 1999; 61:58-68.

129. Esler M, Jennings G, Lambert G. Measurement of overall and cardiac norepinephrine release into plasma during cognitive challenge. Psychoneuroendocrinology 1989; 14:477-81.

130. Light KC, Kothandapani RV, Allen MT. Enhanced cardiovascular and catecholamine responses in women with depressive symptoms. Int $J$ Psychophysiol 1998; 28:157-66.

131. Sheffield D, Krittayaphong R, Cascio WE, Light KC, Golden RN, Finkel JB, Glekas G, Koch GG, Sheps DS. Heart rate variability at rest and during mental stress in patients with coronary artery disease: differences in patients with high and low depression scores. Int J Behav Med 1998; 5:31-47.

132. Hughes JW, Stoney CM. Depressed mood is related to high-frequency heart rate variability during stressors. Psychosom Med 2000; 62:796-803.

133. Hamer M, Tanaka G, Okamura H, Tsuda A, Steptoe A. The effects of depressive symptoms on cardiovascular and catecholamine responses to the induction of depressive mood. Biol Psychol 2007; 74:20-5.

134. Scalco AZ, Rondon MU, Trombetta IC, Laterza MC, Azul JB, Pullenayegum EM, Scalco MZ, Kuniyoshi FH, Wajngarten M, Negrao CE, Lotufo-Neto F. 
Muscle sympathetic nervous activity in depressed patients before and after treatment with sertraline. J Hypertens 2009; 27:2429-36.

135. Barton DA, Dawood T, Lambert EA, Esler MD, Haikerwal D, Brenchley C, Socratous F, Kaye DM, Schlaich MP, Hickie I, Lambert GW. Sympathetic activity in major depressive disorder: identifying those at increased cardiac risk? J Hypertens 2007; 25:2117-24.

136. Lambert EA, Schlaich MP. Reduced sympathoneural responses to the cold pressor test in individuals with essential hypertension and in those genetically predisposed to hypertension. No support for the "pressor reactor" hypothesis of hypertension development. Am J Hypertens 2004; 17:863-8.

137. Grassi G, Seravalle G, Cattaneo BM, Bolla GB, Lanfranchi A, Colombo M, Giannattasio C, Brunani A, Cavagnini F, Mancia G. Sympathetic activation in obese normotensive subjects. Hypertension 1995; 25:560-3.

138. Lambert GW, Straznicky NE, Lambert EA, Dixon JB, Schlaich MP. Sympathetic nervous activation in obesity and the metabolic syndrome--causes, consequences and therapeutic implications. Pharmacol Ther 2010; 126:15972.

139. Grassi G, Dell'Oro R, Facchini A, Quarti Trevano F, Bolla GB, Mancia G. Effect of central and peripheral body fat distribution on sympathetic and baroreflex function in obese normotensives. J Hypertens 2004; 22:2363-9.

140. Straznicky NE, Lambert EA, Lambert GW, Masuo K, Esler MD, Nestel PJ. Effects of dietary weight loss on sympathetic activity and cardiac risk factors associated with the metabolic syndrome. J Clin Endocrinol Metab 2005; 90:5998-6005.

141. Lee ZS, Critchley JA, Tomlinson B, Young RP, Thomas GN, Cockram CS, Chan TY, Chan JC. Urinary epinephrine and norepinephrine interrelations with obesity, insulin, and the metabolic syndrome in Hong Kong Chinese. Metabolism 2001; 50:135-43.

142. Brunner EJ, Hemingway H, Walker BR, Page M, Clarke P, Juneja M, Shipley MJ, Kumari M, Andrew R, Seckl JR, Papadopoulos A, Checkley S, Rumley A, Lowe GD, Stansfeld SA, Marmot MG. Adrenocortical, autonomic, and inflammatory causes of the metabolic syndrome: nested case-control study. Circulation 2002; 106:2659-65.

143. Vaz M, Jennings G, Turner A, Cox H, Lambert G, Esler M. Regional sympathetic nervous activity and oxygen consumption in obese normotensive human subjects. Circulation 1997; 96:3423-9.

144. La Rovere MT, Bigger JT, Jr., Marcus FI, Mortara A, Schwartz PJ. Baroreflex sensitivity and heart-rate variability in prediction of total cardiac mortality after myocardial infarction. ATRAMI (Autonomic Tone and Reflexes After Myocardial Infarction) Investigators. Lancet 1998; 351:478-84.

145. Vingerhoets A. Psychosocial Stress: An Experimental Approach. Life Events, Coping, and Psychobiological Functioning. Groningen, The Netherlands: Swets \& Zeitlinger, 1985.

146. Selye H. The Stress of Life. New York: McGraw-Hill, 1956.

147. Gold PW, Goodwin FK, Chrousos GP. Clinical and biochemical manifestations of depression. Relation to the neurobiology of stress (1). N Engl J Med 1988; 319:348-53.

148. Gold PW, Goodwin FK, Chrousos GP. Clinical and biochemical manifestations of depression. Relation to the neurobiology of stress (2). N Engl J Med 1988; 319:413-20. 
149. Chrousos GP, Gold PW. The concepts of stress and stress system disorders. Overview of physical and behavioral homeostasis. JAMA 1992; 267:1244-52.

150. Carroll, Curtis GC, Mendels J. Neuroendocrine regulation in depression. I. Limbic system-adrenocortical dysfunction. Arch Gen Psychiatry 1976; 33:1039-44.

151. Asnis GM, Halbreich U, Ryan ND, Rabinowicz H, Puig-Antich J, Nelson B, Novacenko H, Friedman JH. The relationship of the dexamethasone suppression test ( $1 \mathrm{mg}$ and $2 \mathrm{mg}$ ) to basal plasma cortisol levels in endogenous depression. Psychoneuroendocrinology 1987; 12:295-301.

152. Coryell W, Schlesser M. The dexamethasone suppression test and suicide prediction. Am J Psychiatry 2001; 158:748-53.

153. Nemeroff CB, Widerlov E, Bissette G, Walleus H, Karlsson I, Eklund K, Kilts CD, Loosen PT, Vale W. Elevated concentrations of CSF corticotropinreleasing factor-like immunoreactivity in depressed patients. Science 1984; 226:1342-4.

154. Banki CM, Bissette G, Arato M, O'Connor L, Nemeroff CB. CSF corticotropinreleasing factor-like immunoreactivity in depression and schizophrenia. Am J Psychiatry 1987; 144:873-7.

155. Banki CM, Karmacsi L, Bissette G, Nemeroff CB. CSF corticotropin-releasing hormone and somatostatin in major depression: response to antidepressant treatment and relapse. Eur Neuropsychopharmacol 1992; 2:107-13.

156. Raadsheer FC, van Heerikhuize JJ, Lucassen PJ, Hoogendijk WJ, Tilders FJ, Swaab DF. Corticotropin-releasing hormone mRNA levels in the paraventricular nucleus of patients with Alzheimer's disease and depression. Am J Psychiatry 1995; 152:1372-6.

157. Sirinathsinghji DJ, Rees LH, Rivier J, Vale W. Corticotropin-releasing factor is a potent inhibitor of sexual receptivity in the female rat. Nature 1983; 305:2325.

158. Glowa JR, Gold PW. Corticotropin releasing hormone produces profound anorexigenic effects in the rhesus monkey. Neuropeptides 1991; 18:55-61.

159. Brown MR, Fisher LA, Spiess J, Rivier C, Rivier J, Vale W. Corticotropinreleasing factor: actions on the sympathetic nervous system and metabolism. Endocrinology 1982; 111:928-31.

160. Forbes LM, Chaney RH. Cardiovascular changes during acute depression. Psychosomatics 1980; 21:472-7.

161. Carney RM, Freedland KE, Rich MW, Smith LJ, Jaffe AS. Ventricular tachycardia and psychiatric depression in patients with coronary artery disease. Am J Med 1993; 95:23-8.

162. Heidland UE, Strauer BE. Left ventricular muscle mass and elevated heart rate are associated with coronary plaque disruption. Circulation 2001; 104:147782.

163. Carney RM, Rich MW, teVelde A, Saini J, Clark K, Freedland KE. The relationship between heart rate, heart rate variability and depression in patients with coronary artery disease. J Psychosom Res 1988; 32:159-64.

164. Dyer AR, Persky V, Stamler J, Paul O, Shekelle RB, Berkson DM, Lepper M, Schoenberger JA, Lindberg HA. Heart rate as a prognostic factor for coronary heart disease and mortality: findings in three Chicago epidemiologic studies. Am J Epidemiol 1980; 112:736-49. 
165. Kannel WB, Kannel C, Paffenbarger RS, Jr., Cupples LA. Heart rate and cardiovascular mortality: the Framingham Study. Am Heart J 1987; 113:148994.

166. Palatini P, Julius S. Association of tachycardia with morbidity and mortality: pathophysiological considerations. J Hum Hypertens 1997; 11 Suppl 1:S1927.

167. Gordon D, Guyton JR, Karnovsky MJ. Intimal alterations in rat aorta induced by stressful stimuli. Lab Invest 1981; 45:14-27.

168. Troxler RG, Sprague EA, Albanese RA, Fuchs R, Thompson AJ. The association of elevated plasma cortisol and early atherosclerosis as demonstrated by coronary angiography. Atherosclerosis 1977; 26:151-62.

169. Kaplan J, Pettersson K, Manuck SB, Olsson G. Role of sympathoadrenal medullary activation in the initiation and progression of atherosclerosis. Circulation 1991; 84:VI23-32.

170. Colao A, Pivonello R, Spiezia S, Faggiano A, Ferone D, Filippella M, Marzullo P, Cerbone G, Siciliani M, Lombardi G. Persistence of increased cardiovascular risk in patients with Cushing's disease after five years of successful cure. J Clin Endocrinol Metab 1999; 84:2664-72.

171. Goldberg AD, Becker LC, Bonsall R, Cohen JD, Ketterer MW, Kaufman PG, Krantz DS, Light KC, McMahon RP, Noreuil T, Pepine CJ, Raczynski J, Stone PH, Strother D, Taylor H, Sheps DS. Ischemic, hemodynamic, and neurohormonal responses to mental and exercise stress. Experience from the Psychophysiological Investigations of Myocardial Ischemia Study (PIMI). Circulation 1996; 94:2402-9.

172. Krantz DS, Helmers KF, Bairey CN, Nebel LE, Hedges SM, Rozanski A. Cardiovascular reactivity and mental stress-induced myocardial ischemia in patients with coronary artery disease. Psychosom Med 1991; 53:1-12.

173. Resstel LB, Fernandes KB, Correa FM. Medial prefrontal cortex modulation of the baroreflex parasympathetic component in the rat. Brain Res 2004; 1015:136-44.

174. Rajkowska G. Postmortem studies in mood disorders indicate altered numbers of neurons and glial cells. Biol Psychiatry 2000; 48:766-77.

175. Yudkin JS, Kumari M, Humphries SE, Mohamed-Ali V. Inflammation, obesity, stress and coronary heart disease: is interleukin-6 the link? Atherosclerosis 2000; 148:209-14.

176. Berntson GG, Norman GJ, Hawkley LC, Cacioppo JT. Cardiac autonomic balance versus cardiac regulatory capacity. Psychophysiology 2008; 45:64352.

177. Thayer JF, Sternberg E. Beyond heart rate variability: vagal regulation of allostatic systems. Ann N Y Acad Sci 2006; 1088:361-72.

178. Goldberger AL, West BJ. Applications of nonlinear dynamics to clinical cardiology. Ann N Y Acad Sci 1987; 504:195-213.

179. Carney RM, Blumenthal JA, Stein PK, Watkins L, Catellier D, Berkman LF, Czajkowski SM, O'Connor C, Stone PH, Freedland KE. Depression, heart rate variability, and acute myocardial infarction. Circulation 2001; 104:2024-8.

180. Rottenberg J. Cardiac vagal control in depression: a critical analysis. Biol Psychol 2007; 74:200-11.

181. Higgins CB, Vatner SF, Braunwald E. Parasympathetic control of the heart. Pharmacol Rev 1973; 25:119-55. 
182. Berntson GG, Cacioppo JT, Quigley KS. Autonomic determinism: the modes of autonomic control, the doctrine of autonomic space, and the laws of autonomic constraint. Psychol Rev 1991; 98:459-87.

183. Curtis BM, O'Keefe JH, Jr. Autonomic tone as a cardiovascular risk factor: the dangers of chronic fight or flight. Mayo Clin Proc 2002; 77:45-54.

184. Huikuri HV, Makikallio TH. Heart rate variability in ischemic heart disease. Auton Neurosci 2001; 90:95-101.

185. Tsuji H, Larson MG, Venditti FJ, Jr., Manders ES, Evans JC, Feldman CL, Levy D. Impact of reduced heart rate variability on risk for cardiac events. The Framingham Heart Study. Circulation 1996; 94:2850-5.

186. Pedretti R, Etro MD, Laporta A, Sarzi Braga S, Caru B. Prediction of late arrhythmic events after acute myocardial infarction from combined use of noninvasive prognostic variables and inducibility of sustained monomorphic ventricular tachycardia. Am J Cardiol 1993; 71:1131-41.

187. Bigger JT, Jr., Steinman RC, Rolnitzky LM, Fleiss JL, Albrecht P, Cohen RJ. Power law behavior of RR-interval variability in healthy middle-aged persons, patients with recent acute myocardial infarction, and patients with heart transplants. Circulation 1996; 93:2142-51.

188. Kleiger RE, Miller JP, Bigger JT, Jr., Moss AJ. Decreased heart rate variability and its association with increased mortality after acute myocardial infarction. Am J Cardiol 1987; 59:256-62.

189. Malik M, Farrell T, Camm AJ. Circadian rhythm of heart rate variability after acute myocardial infarction and its influence on the prognostic value of heart rate variability. Am J Cardiol 1990; 66:1049-54.

190. Farrell TG, Bashir Y, Cripps T, Malik M, Poloniecki J, Bennett ED, Ward DE, Camm AJ. Risk stratification for arrhythmic events in postinfarction patients based on heart rate variability, ambulatory electrocardiographic variables and the signal-averaged electrocardiogram. J Am Coll Cardiol 1991; 18:687-97.

191. Casolo GC, Stroder P, Signorini C, Calzolari F, Zucchini M, Balli E, Sulla A, Lazzerini S. Heart rate variability during the acute phase of myocardial infarction. Circulation 1992; 85:2073-9.

192. Bigger JT, Jr., Kleiger RE, Fleiss JL, Rolnitzky LM, Steinman RC, Miller JP. Components of heart rate variability measured during healing of acute myocardial infarction. Am J Cardiol 1988; 61:208-15.

193. Dekker JM, Crow RS, Folsom AR, Hannan PJ, Liao D, Swenne CA, Schouten EG. Low heart rate variability in a 2-minute rhythm strip predicts risk of coronary heart disease and mortality from several causes: the ARIC Study. Atherosclerosis Risk In Communities. Circulation 2000; 102:1239-44.

194. Dekker JM, Schouten EG, Klootwijk P, Pool J, Swenne CA, Kromhout D. Heart rate variability from short electrocardiographic recordings predicts mortality from all causes in middle-aged and elderly men. The Zutphen Study. Am J Epidemiol 1997; 145:899-908.

195. Goldberger AL, Findley LJ, Blackburn MR, Mandell AJ. Nonlinear dynamics in heart failure: implications of long-wavelength cardiopulmonary oscillations. Am Heart J 1984; 107:612-5.

196. Myers GA, Martin GJ, Magid NM, Barnett PS, Schaad JW, Weiss JS, Lesch M, Singer DH. Power spectral analysis of heart rate variability in sudden cardiac death: comparison to other methods. IEEE Trans Biomed Eng 1986; 33:114956. 
197. Hackam DG, Anand SS. Emerging risk factors for atherosclerotic vascular disease: a critical review of the evidence. JAMA 2003; 290:932-40.

198. Noorbakhsh F, Overall CM, Power C. Deciphering complex mechanisms in neurodegenerative diseases: the advent of systems biology. Trends Neurosci 2009; 32:88-100.

199. Alm E, Arkin AP. Biological networks. Curr Opin Struct Biol 2003; 13:193-202.

200. Liljeros F, Edling CR, Amaral LA, Stanley HE, Aberg Y. The web of human sexual contacts. Nature 2001; 411:907-8.

201. Newman ME. The structure of scientific collaboration networks. Proc Natl Acad Sci U S A 2001; 98:404-9.

202. Barabasi AL, Jeong H, Ravasz R, Neda Z, Vicsek T, Schubert A. On the topology of the scientific collaboration networks. Physica A 2002; 311:590.

203. Faloutsos M, Faloutsos P, Faloutsos C. On power-law relationships of the Internet topology. Comput Commu Rev 1999; 29:251-62.

204. Albert R, Jeong H, Barabasi AL. Diameter of the World Wide Web. Nature 1999; 401:130-131.

205. Kitano H. Systems biology: a brief overview. Science 2002; 295:1662-4.

206. Nikolsky Y, Nikolskaya T, Bugrim A. Biological networks and analysis of experimental data in drug discovery. Drug Discov Today 2005; 10:653-62.

207. Dunne JA, Williams RJ, Martinez ND. Food-web structure and network theory: The role of connectance and size. Proc Natl Acad Sci U S A 2002; 99:1291722.

208. Williams RJ, Martinez ND. Simple rules yield complex food webs. Nature 2000; 404:180-3.

209. Barabasi AL, Oltvai ZN. Network biology: understanding the cell's functional organization. Nat Rev Genet 2004; 5:101-13.

210. Ravasz E, Somera AL, Mongru DA, Oltvai ZN, Barabasi AL. Hierarchical organization of modularity in metabolic networks. Science 2002; 297:1551-5. 


\section{List of Figures}

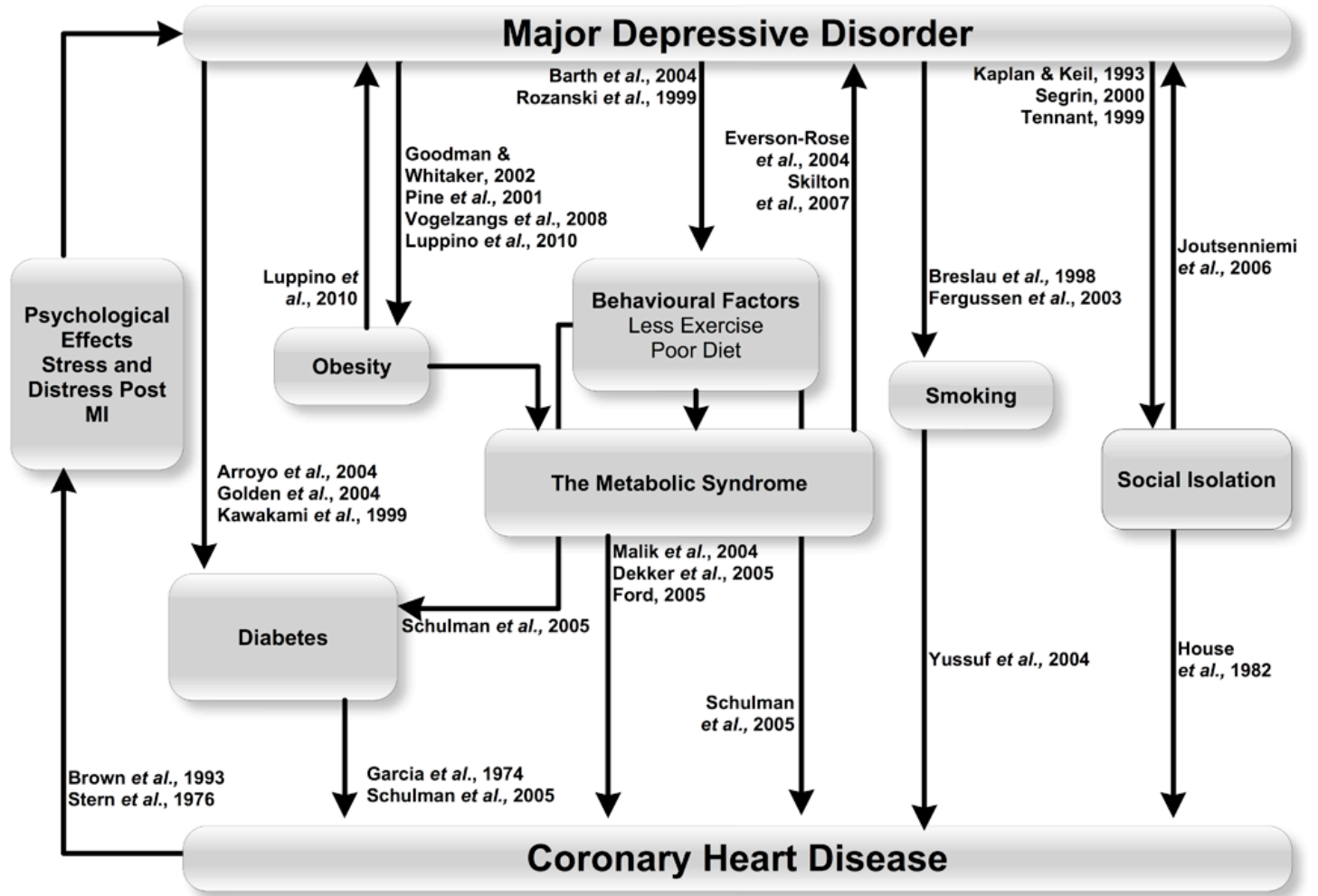

Figure 1 Behavioural Mechanisms Linking Major Depressive Disorder and Coronary Heart Disease 


\section{Major Depressive Disorder}

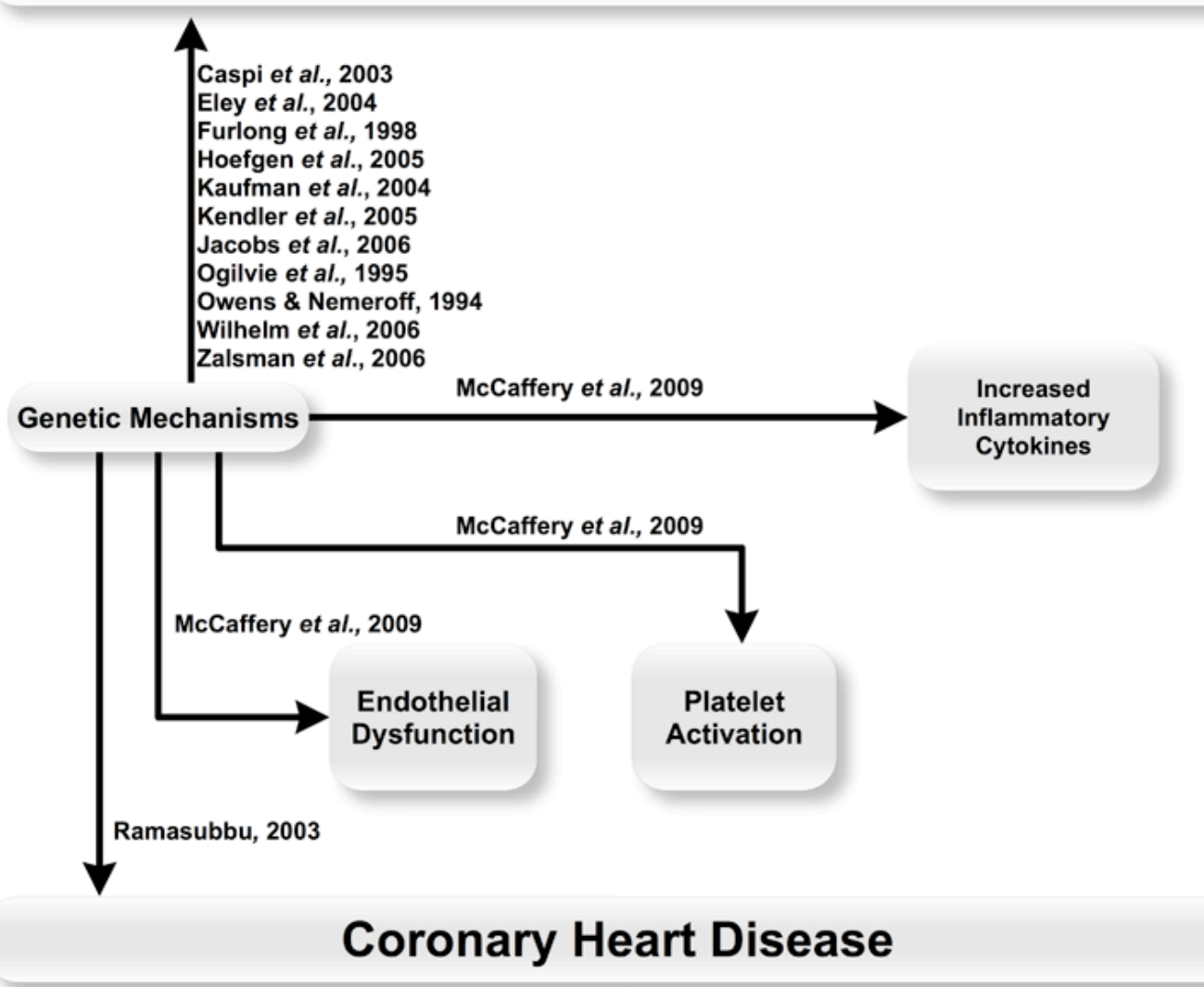

Figure 2 Genetic Mechanisms Linking Major Depressive Disorder and Coronary

Heart Disease 


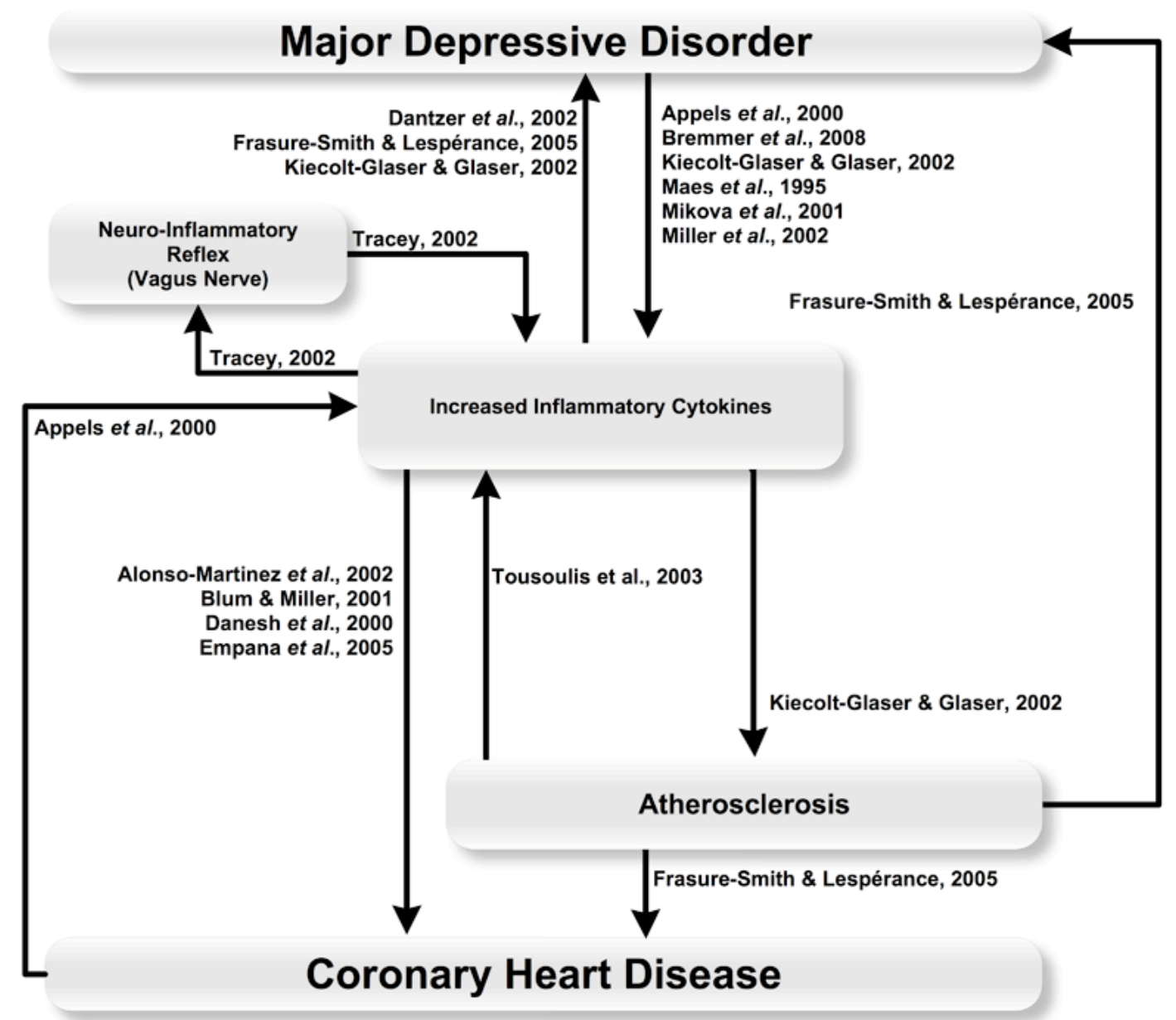

Figure 3 Inflammatory Mechanisms Linking Major Depressive Disorder and Coronary Heart Disease 


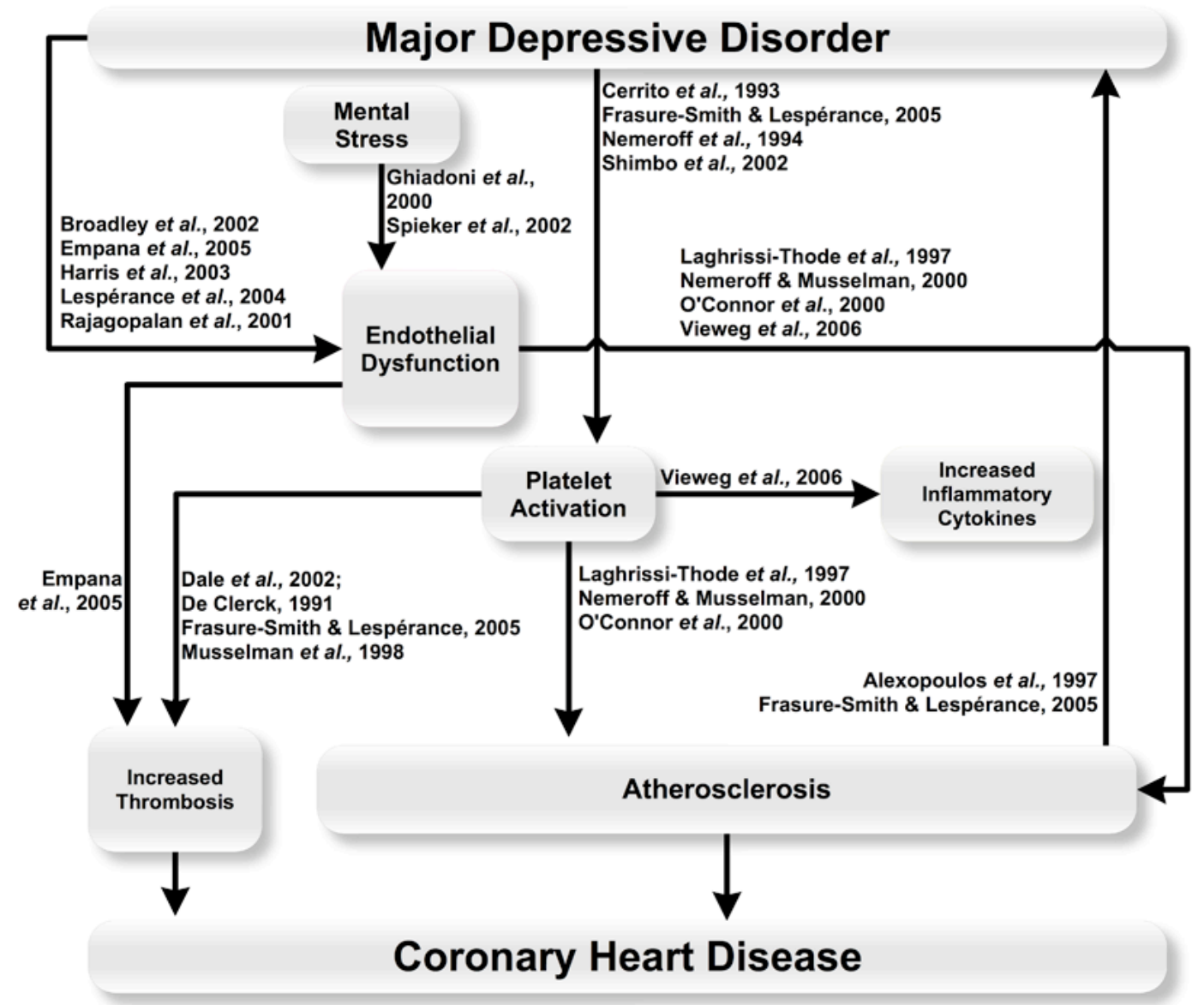

Figure 4 Endothelial and Coagulopathic Mechanisms Linking Major Depressive Disorder and Coronary Heart Disease 


\section{Major Depressive Disorder}

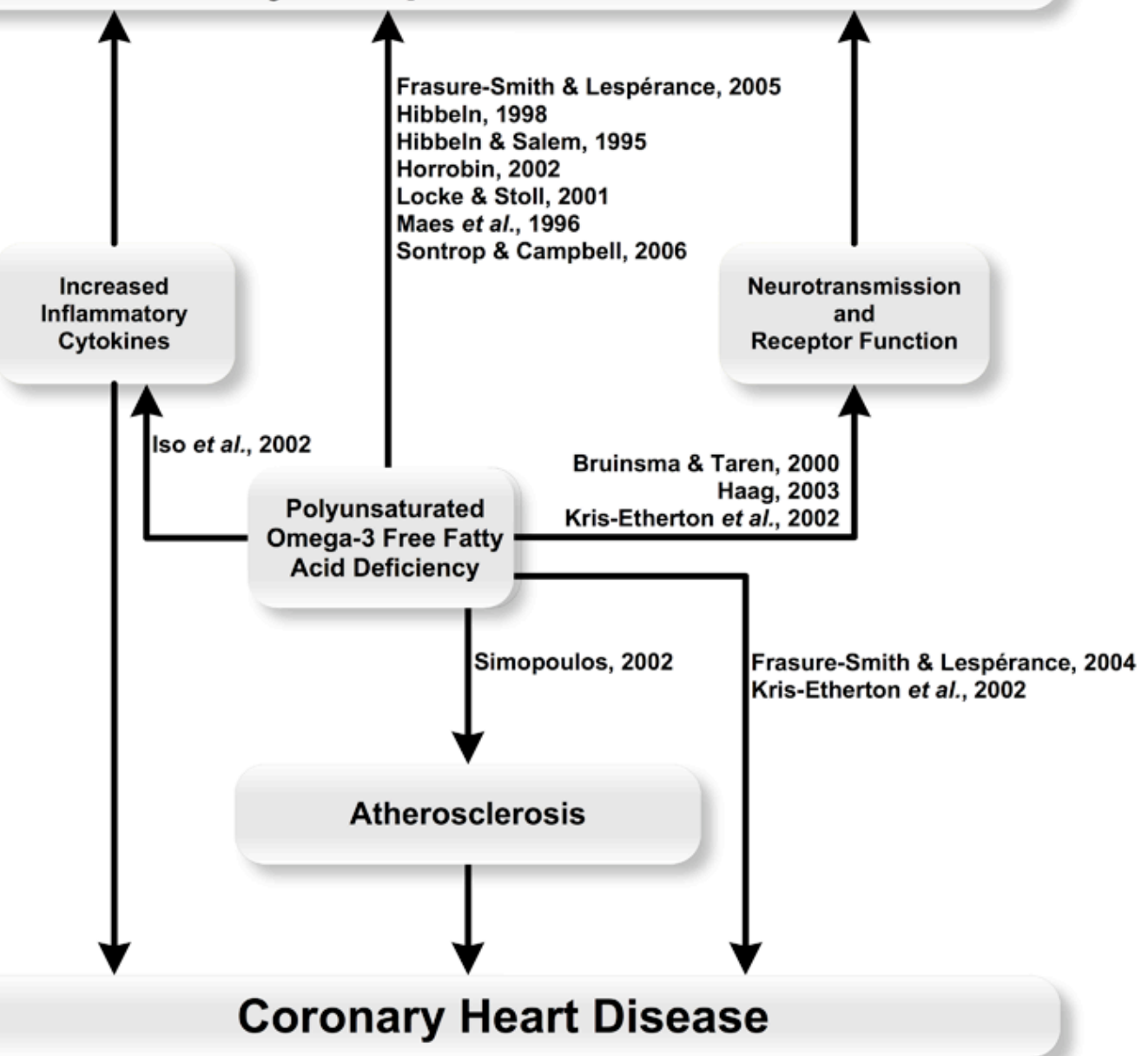

Figure 5 Polyunsaturated Omega-3 Free Fatty Acid Deficiency Linking Major

Depressive Disorder and Coronary Heart Disease 


\section{Major Depressive Disorder}

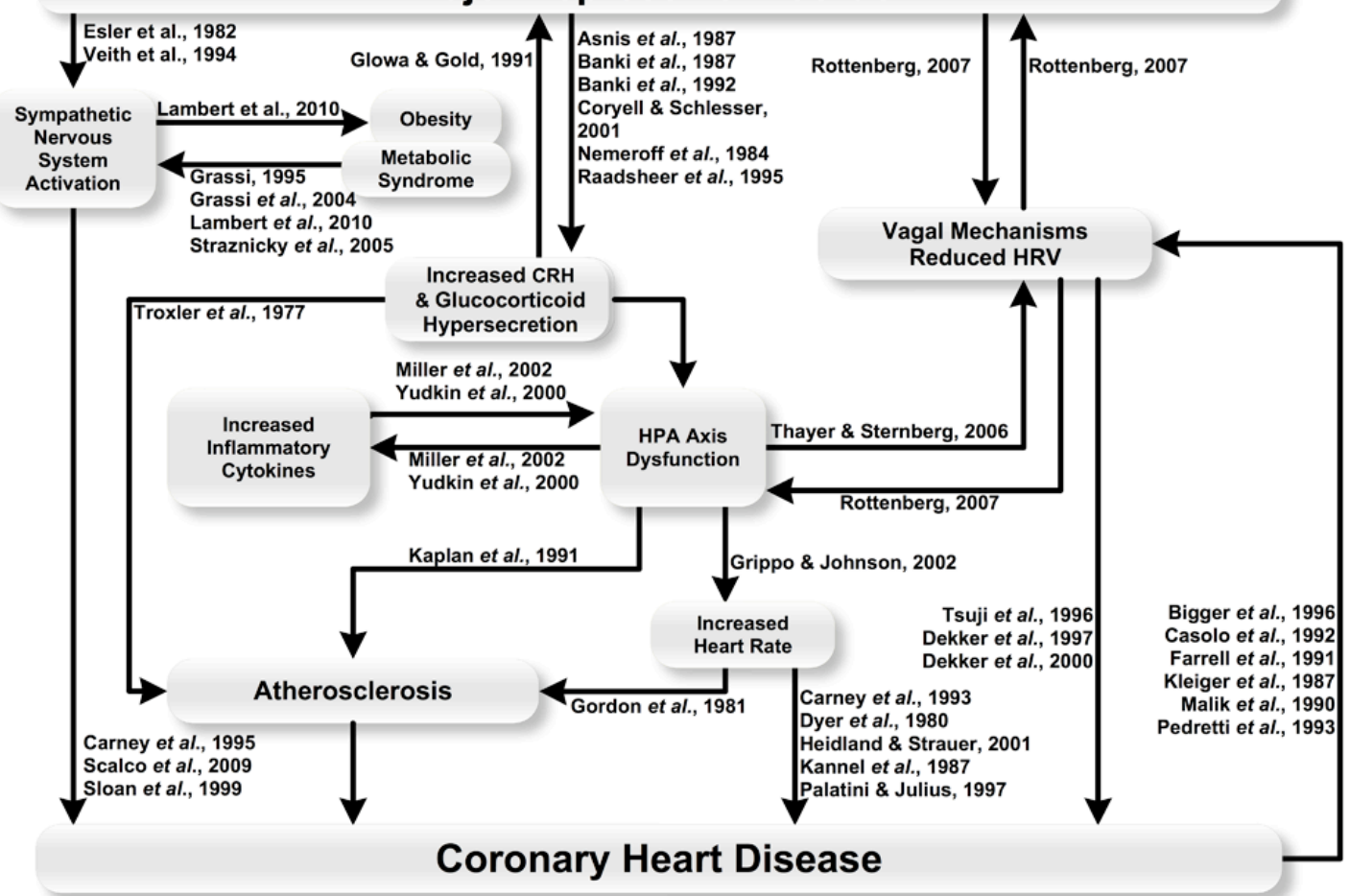

Figure 6 Autonomic Mechanisms Linking Major Depressive Disorder and Coronary Heart Disease 


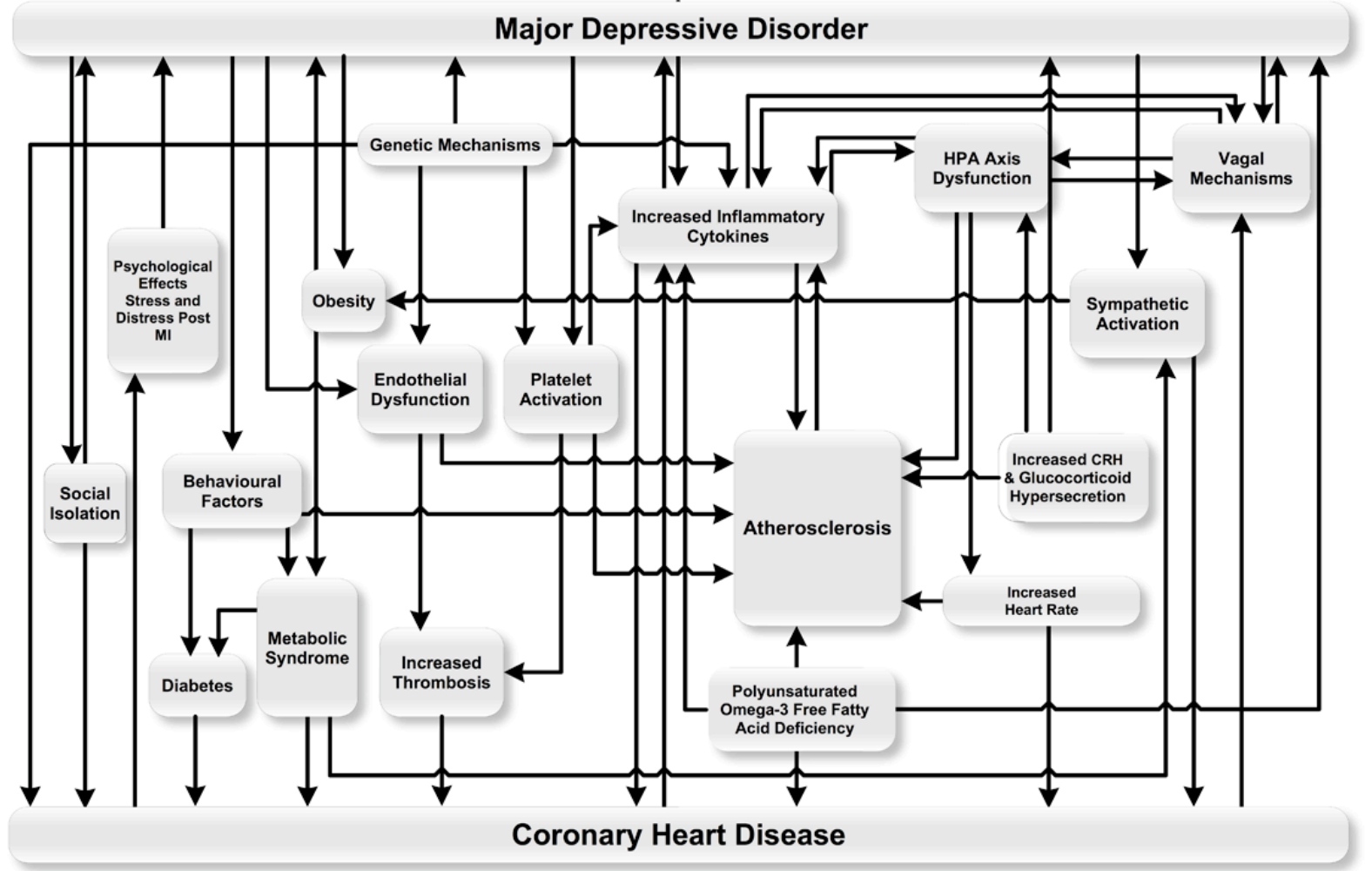

Figure 7 The Relationship Between Major Depressive Disorder and Coronary Heart Disease: A Topographical Map of the Causal Network 